\title{
Integration of In Situ Experiments and Numerical Simulations to Reveal the Physicochemical Circumstances of Organic and Inorganic Precipitation at a Thermal Spring
}

\author{
Petra Kovács-Bodor ${ }^{1}$ D . Dóra Anda ${ }^{2} \cdot$ Laura Jurecska $^{2} \cdot$ Mihály Óvári $^{3}$. \\ Ákos Horváth ${ }^{4}$. Judit Makk ${ }^{2}$. Vincent Post ${ }^{5} \cdot$ Imre Müller $^{1}$ • Judit MádI-Szőnyi ${ }^{1}$
}

Received: 19 February 2018 / Accepted: 27 June 2018 / Published online: 2 July 2018

(C) The Author(s) 2018

\begin{abstract}
Organic and inorganic precipitates are both characteristic in the active hypogenic karst area of Buda Thermal Karst in Hungary. As an active system, it is a good natural laboratory to study ongoing precipitation processes. Because of anthropogenic influence and the complexity of spring environments, it is challenging to reveal all the governing factors in the process of precipitation. In situ experiments, i.e. artificially controlled natural systems simplify the complexity by adding, excluding or stabilizing influencing parameters during the experiment. $\mathrm{CO}_{2}$ degassing drives changes in the physicochemical parameters of spring waters from the discharge along their flow path. The rate and spatial extension of these changes depend on local hydrogeological, geological, climatic, topographical etc. factors, affecting precipitation processes. In this study, two one-day-long in situ experiments were executed to examine the physicochemical parameter changes of thermal water in a tunnel. The integration of the results with reactive transport models revealed the physicochemical processes of ingassing and degassing and predicted $\mathrm{CaCO}_{3}$ precipitation along the flow path. Small-scale roughness of the channel surface seemed to further influence $\mathrm{pH}$ and concentration of $\mathrm{HCO}_{3}{ }^{-}$. After 6 weeks of thermal water flowing, organic precipitate (biofilm) formed close to the discharge and then, with a sharp change, inorganic precipitate (calcite) dominates a bit further from the discharge. In situ experiments and connected numerical simulations revealed the role of $\mathrm{CO}_{2}$ degassing and calcite precipitation in the changes of physicochemical parameters, but organic precipitates also have to be considered near the discharge.
\end{abstract}

Keywords Thermal water · In situ experiment $\cdot$ Physicochemical parameters $\cdot$ Reactive transport modelling · Organic precipitation · Inorganic precipitation

Petra Kovács-Bodor

petra.bodor28@gmail.com

Extended author information available on the last page of the article 


\section{Introduction}

Changes in the physicochemical parameters of springs are observed from their points of outflow along their flow paths. The main driving force of these changes is the degassing of $\mathrm{CO}_{2}$ due to the significant difference between the partial pressure of $\mathrm{CO}_{2}$ in the air and in the water. One consequence of $\mathrm{CO}_{2}$ escape is an increase in $\mathrm{pH}$. Additionally, the oxidative environment, i.e. the air, causes a rise in the dissolved oxygen content of the water. The rate and spatial extension of the variations depends on many factors, such as the change in pressure, the initial physicochemical parameters, the flow velocity and depth of the water, parameters related to the air, and the irregularities of the bottom of the spring or stream bed, i.e. turbulence (Chen et al. 2004; Dandurand et al. 1982; Hammer et al. 2008; Herman and Lorah 1986, 1987; Hoffer-French and Herman 1989, 1990; Lorah and Herman 1988, 1990; Nordstrom et al. 2005; Zhang et al. 2001).

The aquatic chemistry of the outflowing water is dependent on the groundwater flow system feeding the spring (Tóth 1963). In the case of the discharge of a regional groundwater flow system, thermal water rises to the surface, and this is characterized by a low dissolved oxygen content, neutral or acidic $\mathrm{pH}$, a high total dissolved solid (TDS) content, elevated temperature and, usually, a high concentration of $\mathrm{CO}_{2}$ (Goldscheider et al. 2010; Mádl-Szónyi and Tóth 2015; Tóth 1963). As a consequence of these characteristics, the gradient between the discharging thermal water and the air is high, so the physicochemical parameters change abruptly closer to the outflow than in the case of lukewarm and cold springs. The $38.5-93{ }^{\circ} \mathrm{C}$ thermal waters in Yellowstone National Park display remarkable variations in the parameters over the first 6-30 m from the outflow (Nordstrom et al. 2005). In the case of colder waters $\left(9.3-35{ }^{\circ} \mathrm{C}\right)$, however, at locations with similar surface temperatures, a greater distance from the outflow (ranging from $47 \mathrm{~m}$ up to as far as $10 \mathrm{~km}$ ) is required for such differences to be observed (Amundson and Kelly 1987; Dandurand et al. 1982; Das and Mohanti 2015; Dreybrodt el al. 1992; Herman and Lorah 1986, 1987; Hoffer-French and Herman 1989, 1990; Lorah and Herman 1988, 1990).

The latitudinal and altitudinal location of a given spring discharge is another crucial factor in defining the gradient between the water and the air. The temperature, humidity, air pressure, seasonality, daily variations of these parameters are further factors influencing changes in the physicochemical parameters of the flowing water, so as the density and type of vegetation (e.g. Das and Mohanti 2015; Herman and Lorah 1986; Hoffer-French and Herman 1989, 1990).

It is a special case when the spring discharges into a cave. There are no or quite smoothened seasonality and daily variations in air conditions in caves compared to the outside air. Furthermore, in the absence of light, there is no photosynthetic vegetation, but there are plenty of nutrients for chemoautotrophic and chemolithoautotrophic bacteria, which inhabit the walls and the water, usually forming biofilms (e.g. Engel et al. 2001; Sarbu et al. 1996). Biofilms also form in subaerial springs (e.g. Amundson and Kelly 1987; Das and Mohanti 2015; Nordstrom et al. 2005). The bacteria influence their environment via metabolization and therefore take part in the processes of dissolution and precipitation (e.g. Ehrlich 2001).

Carbonates are also common phenomena in caves and springs. The increasing $\mathrm{pH}$ of water causes a rise in the saturation index with respect to calcite $\left(\mathrm{SI}_{\text {calcite }}\right)$ and after reaching the appropriate state of supersaturation, $\mathrm{CaCO}_{3}$ precipitates. Biofilms and carbonates often occur together, connected to the same water body, and characterized by the same water chemistry. Because of that, and the complexity of natural spring systems, it is challenging to measure and take into consideration all the governing factors in the process of 
precipitation. Laboratory experiments are often executed to study the evolution of precipitates and the effects of specific parameters. However, it is not possible to make such a complex system in the laboratory, what exists in the nature. In situ experiments, i.e. artificially controlled natural systems provide a key solution in overcoming these problems. Parameters can be added, excluded or stabilized during the in situ experiment. The changes of the water chemistry and the formation of the precipitates can be followed in time and space.

Based on these preliminary considerations, an in situ experiment was conducted in the active hypogenic karst area of Buda Thermal Karst (BTK) in Hungary, where biofilm formation and carbonate precipitation are active processes (Erôss 2010; Mádl-Szônyi and Erôss 2013). The direct observation of ongoing precipitation processes is possible near the surface in thermal spring caves and hypogenic caves (Erôss 2010), and thus providing an excellent natural laboratory. The thermal springs of the BTK are anthropogenically controlled, so in situ experiments cannot be made at these locations. But there is a canal in the artificial tunnel of Gellért Hill, which is located close to the thermal water discharge in the south part of the BTK. Here, thermal water can be directed into a trapezoid canal, simulating thermal spring discharge in a cave environment. The known and constant initial volume discharge, the easily measurable water chemistry along the flow path and the regular canal profile provide good input data to a reactive transport model. The integration of in situ experiment and numerical simulation gives a detailed picture of the changing physicochemical parameters and the underlying biogeochemical processes.

The aim of the study was to examine the rate and spatial extension of the physicochemical parameter changes of flowing thermal water via an in situ experiment in the "artificial cave" of a natural laboratory to reveal the circumstances of the evolution of organic and inorganic precipitation in advance of their formation. Furthermore, to examine the distribution of radionuclides and trace elements along the flow path of the thermal water, before the adsorbing precipitates form. Besides the measurements, reactive transport modelling was used to simulate the main chemical reactions along the flow path of the thermal water.

\section{The Study Area}

\subsection{Gellért Hill}

The BTK is the regional discharge area of a thick carbonate system lying on the boundary of confined and unconfined carbonates (Mádl-Szőnyi and Tóth 2015). The BTK is situated on the northeastern edge of this carbonate system, the Transdanubian Range (Fig. 1a, b). Hydraulic and hydrochemical studies and the radionuclide analysis of the BTK have assisted in the delineation of the flow components of the discharge area (Erhardt et al. 2017; Erőss et al. 2012; Mádl-Szőnyi et al. 2017a, b). In the Gellért Hill area, only thermal springs, originating from regional groundwater flow systems discharge. These waters are characterized by not only fresh karst water, but by some additional basinal fluid component from the confined part. The discharging thermal water has elevated concentrations of $\mathrm{HCO}_{3}{ }^{-}, \mathrm{Ca}^{2+}, \mathrm{Mg}^{2+}$ and $\mathrm{SO}_{4}{ }^{2-}$ (Erôss 2010; Kovács and Erôss 2017). The basinal fluids, on the other hand, are responsible for the $\mathrm{Na}^{+}, \mathrm{Cl}^{-}, \mathrm{Ra}^{2+}, \mathrm{CO}_{2}, \mathrm{H}_{2} \mathrm{~S}, \mathrm{H}_{2} \mathrm{SiO}_{3}$ and trace element content of the discharging water (Mádl-Szőnyi and Tóth 2015; Mádl-Szőnyi et al. 2017a) (Fig. 2). Associated with the discharge of groundwater flow systems, springs, thermal caves (e.g. Leél-Ôssy 1995; Leél-Ôssy and Surányi 2003; Takács-Bolner and Kraus 1989), inorganic and organic precipitates are to be found in this specific hydrogeologic 
a
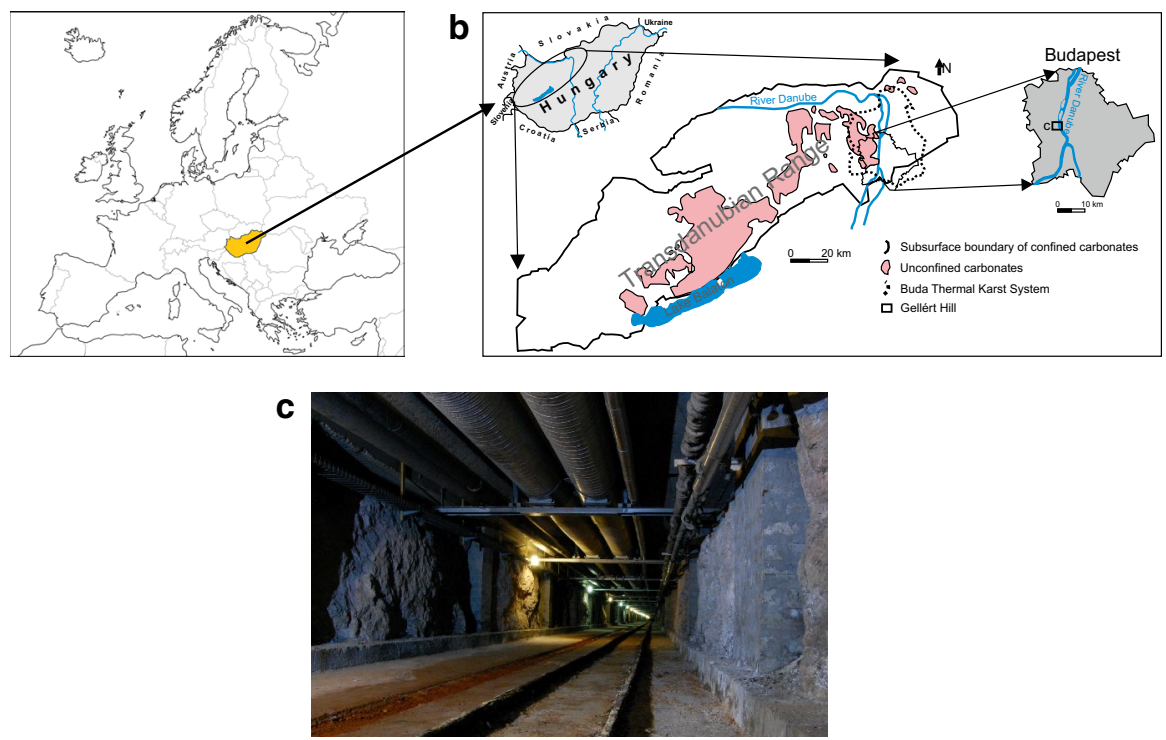

Fig. 1 a Location of Hungary in Europe, $\mathbf{b}$ the study area in the Transdanubian Range (modified after Fülöp in Haas 2001; Mádl-Szőnyi et al. 2001) and c the Gellért tunnel

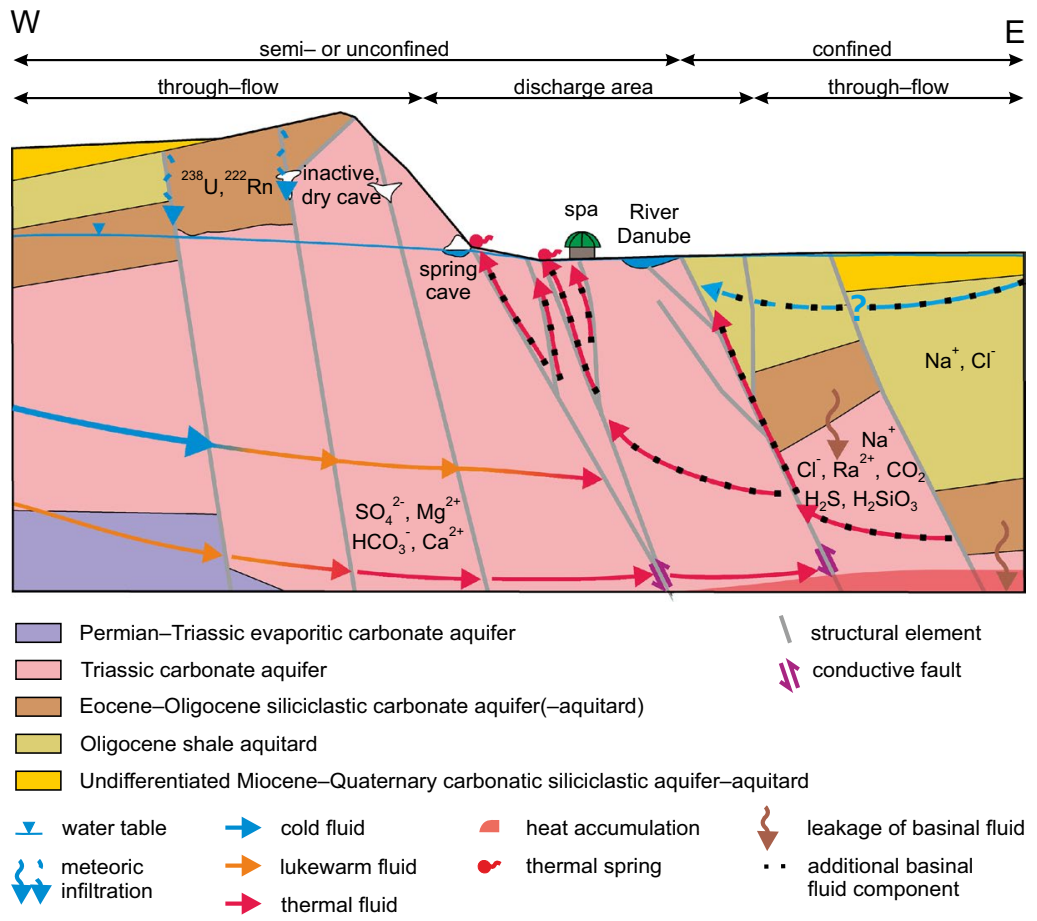

Fig. 2 Conceptual hydrogeological model of the Gellért Hill discharge area (Erôss 2010 modified by MádlSzőnyi et al. 2017a) 
environment (Erôss 2010; Mádl-Szőnyi and Erôss 2013). It has been discovered that biofilms are formed where the discharging reduced thermal water become oxidized, i.e. meets the air (Borsodi et al. 2012; Erôss et al. 2012). Bacteria, inhabiting the biofilms, take part mainly in the iron and sulphur cycle via iron (FeII)/sulphur-oxidation or iron(FeIII)/sulphate-reduction (Anda et al. 2014, 2015; Borsodi et al. 2012; Makk et al. 2016). Furthermore, biofilms in spring caves and springs can adsorb ${ }^{226} \mathrm{Ra}$ from the water and are responsible for the elevated ${ }^{222} \mathrm{Rn}$ content of thermal springs in the BTK (Erôss et al. 2012), similar phenomena have been observed in Japan (Fujisawa and Tazaki 2003; Nagai et al. 2001; Tazaki 2009) and in Switzerland (Gainon et al. 2007). Trace elements also tend to accumulate in biofilms (Dobosy et al. 2016; Le Guern et al. 2003).

\subsection{Location of the In Situ Experiment}

A canal in an artificial tunnel in Gellért Hill was the location of the in situ experiment. The tunnel was built between 1969 and 1978 to act as a gallery and to supply the spas of Buda
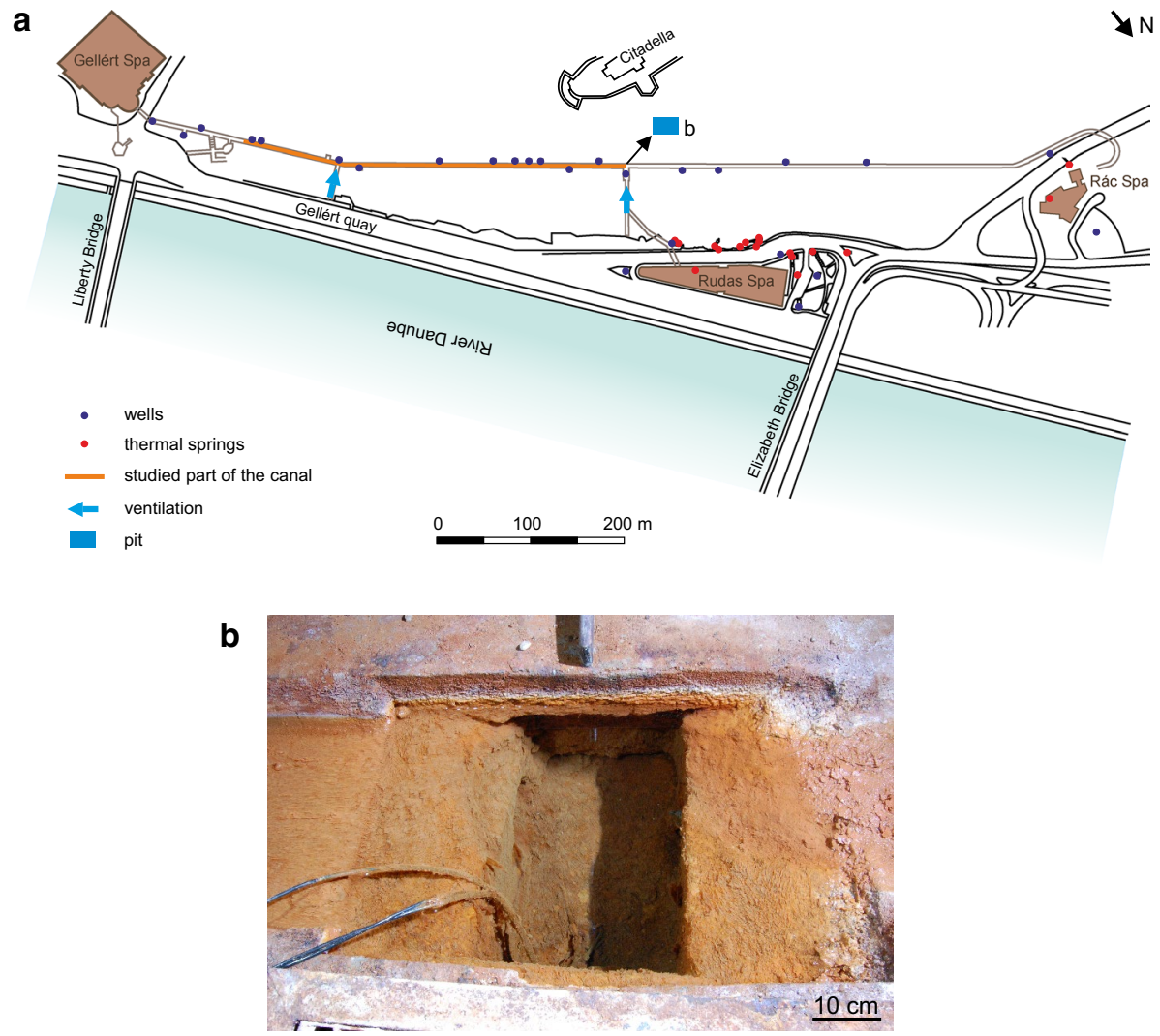

Fig. 3 a Route of the Gellért tunnel, with the location of spas, wells, thermal springs, ventilation ducts and the pit and $\mathbf{b}$ the pit 
along the River Danube with unpolluted thermal water. The tunnel is 1100 metres long and situated by 2-3 $\mathrm{m}$ above the groundwater level. It connects three spas (Fig. 3a).

The groundwater and Danube are hydraulically connected, so when the river floods, the river water pushes the discharge of thermal water down into river bed, causing the shifting of this extra thermal water discharge to the river bank (Alföldi et al. 1968; Schafarzik 1920; Somogyi 2009; Striczki 2010 etc.). Consequently, during floods the tunnel is submerged under thermal water. To facilitate access to the tunnel during these high-water episodes and control the outflowing water, pits (Fig. 3b) and a trapezoid canal (average size: bases 27 and $39 \mathrm{~cm}$, legs 9 and $7 \mathrm{~cm}$ ) have been excavated into the concrete floor of the tunnel.

A 400-m-long section of the canal was studied in the course of the in situ experiment, because thermal water discharges in the area of Gellért Hill at a temperature of $31.4-46.7{ }^{\circ} \mathrm{C}$ (Erôss et al. 2012), so the gradient is high and fast changes are to be expected in the physiochemical parameters of the water, surely stabilizing in the 400-m-long section.

Based on measurements made within the in situ experiment, two main factors influence the air temperature in the tunnel (Weidinger et al. 2016). The first is the presence of the district heating pipes of the city, which are attached to and follow the ceiling of the tunnel. The second is the location of various junctions and ventilation ducts. In the studied 400-m-long section of the tunnel, there are two places where fresh air can enter. One is where the thermal water outflows from the pit (at the Rudas Spa junction) and the other is at a distance of around $300 \mathrm{~m}$ from the pit (Fig. 3).

\section{Data and Methods}

\subsection{Experimental Settings}

The in situ experiments were carried out when the water level of the Danube was relatively low, so the effects of flood could be excluded. To provide thermal water outflow, a pump (Barwig BWV 01 low voltage submersible pump) was inserted into the pit (width * length * depth: $25 * 35 * 39 \mathrm{~cm}$ ) (Fig. 3b) at the Rudas Spa junction. This pump ensured a constant and manageable level of water discharge.

The one-day-long experiment was performed on two separate occasions, 23 March 2016 and 22 April 2016. On both occasions, pumping was started a few hours before the measurements to ensure the water filled the entire examined length $(400 \mathrm{~m})$ of the canal. Later on, the experiment was repeated for 6 weeks to study the thermal water precipitates, to validate the results of the integration of one-day-long experiments and numerical simulations.

\subsection{Measured and Sampled Parameters, Sampling Strategy and Procedure}

On both experimental occasions, parameters were measured at defined distances from the pit, i.e. from the outflow of the thermal water. Those parameters were measured which can influence precipitation processes or can be affected by the precipitates (temperature, $\mathrm{pH}$, specific electric conductivity, dissolved oxygen content, concentration of anions, cations and trace elements, activity of ${ }^{226} \mathrm{Ra}$ and ${ }^{222} \mathrm{Rn}$ ). The location of the March sampling points may be seen in Fig. 4a. The sampling density was more frequent over the first $50 \mathrm{~m}$ based on the literature, i.e. the physicochemical parameters of the thermal water change fast close to the outflow. Temperature, specific electric conductivity, $\mathrm{pH}$, dissolved oxygen content, 
a Distance from the outflow $(\mathrm{m})$
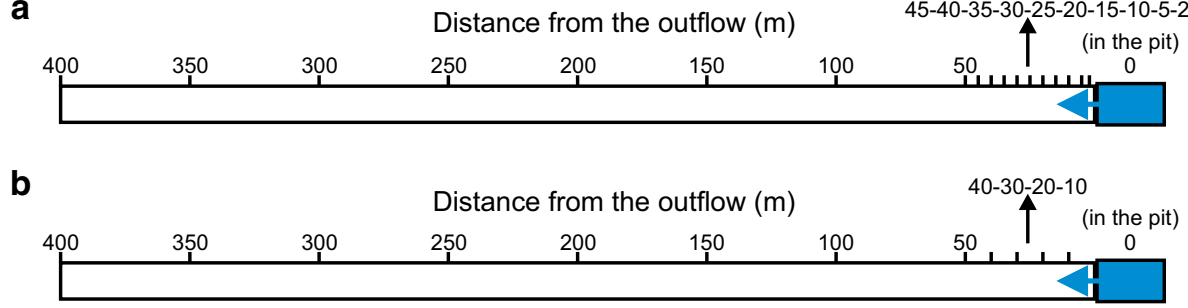

opened pit (outflow) $\quad$ direction of water flow 100 sampling points

Fig. 4 Sampling points of the in situ experiment along the flow path on a 23rd March and b 22nd April 2016

concentration of $\mathrm{HCO}_{3}{ }^{-}$and water discharge were recorded on site. Furthermore, samples were collected for laboratory measurement of major ion analysis $\left(\mathrm{Ca}^{2+}, \mathrm{Mg}^{2+}, \mathrm{Na}^{+}, \mathrm{K}^{+}\right.$, $\mathrm{Cl}^{-}, \mathrm{SO}_{4}{ }^{2-}$ ) from the pit and at distances of 50 and $400 \mathrm{~m}$ in order to obtain a general overview of the changes in ion concentrations. As calcite is the main evolving precipitate in the area, only $\mathrm{Ca}^{2+}$ and $\mathrm{HCO}_{3}{ }^{-}$were measured on site at every sampling point.

In the course of the second experimental session, the location of sampling points (Fig. 4b) was modified based on the results of the first one. The number of measured parameters was also increased. Besides the parameters measured earlier, samples were also collected for the laboratory measurement of ${ }^{226} \mathrm{Ra}$ and ${ }^{222} \mathrm{Rn}$ from all sampling points and for the analysis of trace elements from the pit. As water temperature is the parameter most sensitive to the variations of air conditions, air temperature was also monitored during the second sampling session to understand the effects of the heating pipes and the ventilation ducts.

\subsection{Applied Methods}

The applied methods, the accuracy/detection limit of the measurements and the laboratories are summarized in Table 1. The major ions were determined with the usual analytical laboratory techniques, following standard methods (Eaton et al. 2005). For these measurements, samples were collected in 1.5 1 PET bottles with no free head space and were kept cool until the analysis (within 1-2 days).

To determine ${ }^{222} \mathrm{Rn}$ activity, $10 \mathrm{ml}$ samples were injected into glass vials containing $10 \mathrm{ml}$ Optifluor-O cocktail at the site. The cap of the vial was additionally wrapped with parafilm. The activity was determined within $24 \mathrm{~h}$ because of the short half-life of the isotope (3.82 days).

For ${ }^{226} \mathrm{Ra}$ sampling, 0.251 PET bottles were used. The radionuclides were measured using Nucfilm discs (Surbeck 2000). The samples were kept cool between the sampling and the measurements (within 3-4 weeks).

On the second occasion, samples of trace elements for analysis were collected in $15 \mathrm{ml}$ polypropylene tubes. At each sampling point, both an unfiltered and a $0.2 \mu \mathrm{m}$ filtered sample were taken, in order to determine the distribution of the trace elements between the dissolved and suspended matter. The samples were acidified with $\mathrm{HNO}_{3}$ on site to ensure a $\mathrm{pH}$ of $<1$. After adding $10 \mu \mathrm{g} / \mathrm{l}$ indium internal standard, the analysis 


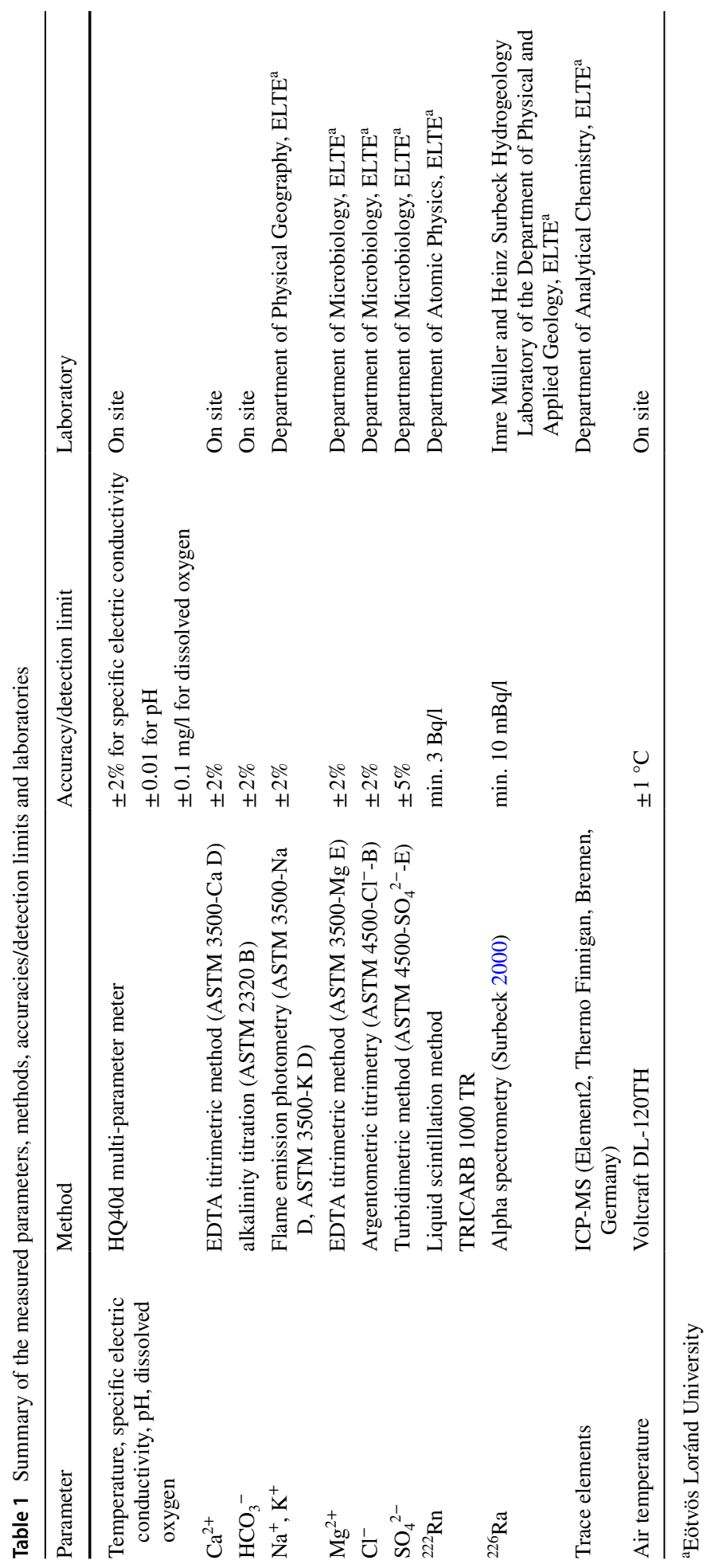


was carried out with the use of inductively coupled plasma-mass spectrometry (ICPMS). Quantification was performed following the external calibration method.

Water discharge was measured by scaling at the outflow of thermal water. Along the flow path of the canal, discharge was calculated from flow velocities determined by surface floating method and trapezoid sections of the canal.

Air temperature was measured about 20 centimetres above the bottom of the tunnel.

To support the interpretation of the concentration patterns measured in March and April, reactive transport modelling was conducted using the PHREEQC code (Parkhurst and Appelo 2013). The reactions considered were similar to those in the work of Keppel et al. (2012) in their study of spring outflow into a wetland, i.e. gas exchange between the water and atmosphere and calcite precipitation. In the present study, the degassing of $\mathrm{CO}_{2}$ and ${ }^{222} \mathrm{Rn}$ and the ingassing of $\mathrm{O}_{2}$ were modelled using the rate expression, Eq. (1):

$$
r=k\left(m-m_{\mathrm{eq}}\right)
$$

where $r$ is the rate of gas transfer between the water and the air in the tunnel $(\mathrm{M} / \mathrm{s}$, where $\mathrm{M}$ is molality), $k$ is the gas exchange rate constant (1/s), $m$ is the concentration of the gas (M), and $m_{\mathrm{eq}}$ is the concentration of the gas in equilibrium with the water at the prevailing temperature (M). The latter value is calculated using PHREEQC. Calcite precipitation was modelled using the kinetic rate equation developed by Plummer et al. (1978). This rate expression is implemented in the standard database of PHREEQC (phreeqc.dat) used in this study. The gas exchange rate constant $k$ depends on several factors, including turbulent dissipation at the air-water interface, water depth, flow velocity, the kinematic viscosity of the water, and the diffusion rate of the gas (Raymond et al. 2012). While theoretical relationships are available to calculate $k$, poor agreement has been reported between these and values of $k$ measured in tracer injection experiments (Genereux and Hamond 1992). In the present study, the value of $k$ was therefore optimized by fitting the model to the measured concentrations.

The morphology of the evolved precipitates was examined by scanning electron microscopy (SEM). The samples were filtered onto $0.2 \mu \mathrm{m}$ polycarbonate filter (Millipore) fixed in glutaraldehyde (5\% in $0.1 \mathrm{M}$ phosphate buffer) for $4-5 \mathrm{~h}$ at room temperature. The fixed samples were rinsed twice with phosphate buffer solution $(\mathrm{pH} 7)$, shock frozen in liquid nitrogen and freeze-dried (until $2 \times 10^{-2}$ mbar, at $-60{ }^{\circ} \mathrm{C}$ for $6-8 \mathrm{~h}$ ). After lyophilization, the dried samples were mounted on metal stubs, and sputter-coated with gold. The samples were examined using an EVO MA 10 Zeiss scanning electron microscope at an accelerating voltage of $10 \mathrm{kV}$.

The mineral composition of the crystalline precipitates was investigated by X-ray powder diffractometer (XRD), using a Siemens D5000 type device (Bragg-Brentano setup, Cu radiation). 


\section{Results of the In Situ Experiment}

\subsection{Field Parameters and Major Ions}

Water temperature decreased overall from 36 to $32.6{ }^{\circ} \mathrm{C}$ in the first session, and from 36.9 to $31.5^{\circ} \mathrm{C}$ in the second. In the first occasion, the temperature dropped from 36 to $30.8^{\circ} \mathrm{C}$ over the first $200 \mathrm{~m}$ and then increased to $32.6^{\circ} \mathrm{C}$. In the second session, the water temperature dropped $\left(36.9-33.2^{\circ} \mathrm{C}\right)$ over the first $150 \mathrm{~m}$, then increased $\left(33.2-34.2^{\circ} \mathrm{C}\right)$ by $250 \mathrm{~m}$, and decreased again $\left(34.2-31.5^{\circ} \mathrm{C}\right)$ (Fig. 5).

The air temperature ranged from 35 to $37^{\circ} \mathrm{C}$ (Fig. 5). $50 \mathrm{~m}$ from the pit it increased, then it became stable, decreasing after $300 \mathrm{~m}$.

The change in $\mathrm{pH}$ was very sharp. The thermal water in the pit was slightly acidic (6.84; 6.79), and it changed to alkaline $(8.05 ; 8.42)$ between the two ends. In the March sampling session, $\mathrm{pH}$ increased rapidly, 6.84-7.84, between the pit and the $25 \mathrm{~m}$ point. Between 25

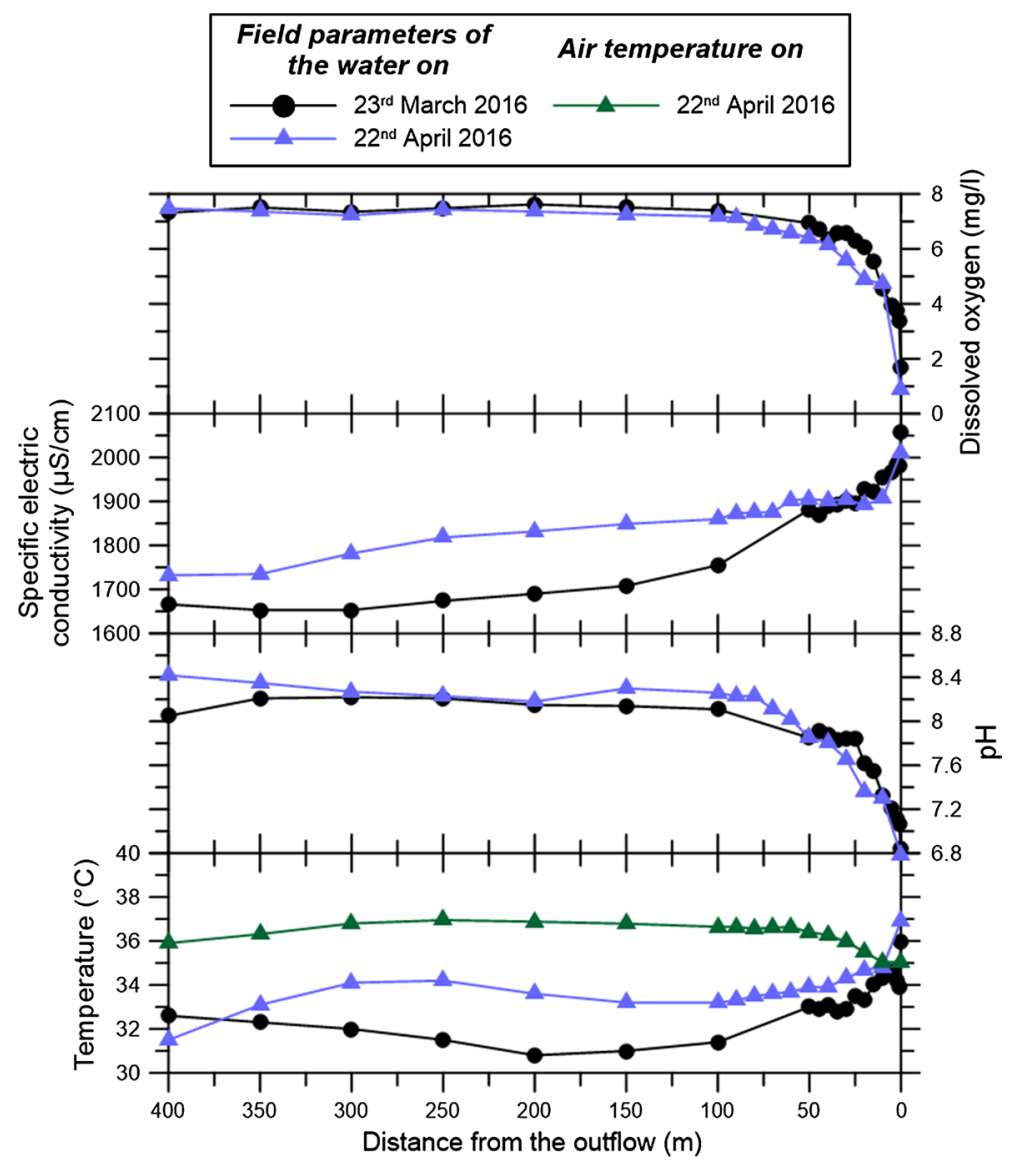

Fig. 5 Variations in the field parameters along the flow path for the two occasions (error of measurements: DO: $\pm 0.1 \mathrm{mg} / \mathrm{l}, \mathrm{EC}: \pm 2 \%, \mathrm{pH}: \pm 0.01, T: \pm 1{ }^{\circ} \mathrm{C}$ ) 
and $50 \mathrm{~m}$, it was stable at around 7.8. Then, it increased slightly to 8.22 and finally dropped to 8.05 at the end of the canal. In April, $\mathrm{pH}$ increased abruptly from 6.79 to 8.23 between the pit and the $80 \mathrm{~m}$ point. After $80 \mathrm{~m}$, it barely changed (Fig. 5).

Dissolved oxygen increased along the flow path on both occasions. In the first case, it was $1.7 \mathrm{mg} / \mathrm{l}$ at the pit and $7.3 \mathrm{mg} / \mathrm{l}$ at $400 \mathrm{~m}$. It changed rapidly between the pit and $100 \mathrm{~m}$, then at a lower rate. On the second occasion, it changed from 0.9 to $7.5 \mathrm{mg} / \mathrm{l}$, with an abrupt rise between the pit and the $100 \mathrm{~m}$ point (Fig. 5).

Specific electric conductivity decreased from 2059 to $1666 \mu \mathrm{S} / \mathrm{cm}$ in March and from 2011 to $1732 \mu \mathrm{S} / \mathrm{cm}$ in April. In both sampling sessions, the greater part of the drop in specific electric conductivity took place over the first $100 \mathrm{~m}$ (Fig. 5).

At the outflow of the thermal water, the volume discharge was an average of $1.8 \times 10^{-4} \mathrm{~m}^{3} / \mathrm{s}$ in March and $1.2 \times 10^{-4} \mathrm{~m}^{3} / \mathrm{s}$ in April. The measured volume discharge was $2.14 \times 10^{-4} \mathrm{~m}^{3} / \mathrm{s}$ in the canal in March and fell between $3.57 \times 10^{-5}$ and $3.61 \times 10^{-4} \mathrm{~m}^{3} / \mathrm{s}$ in April.

The concentration of $\mathrm{HCO}_{3}{ }^{-}$and $\mathrm{Ca}^{2+}$ decreased along the whole flow path from 531 to $295 \mathrm{mg} / \mathrm{l}$ and from 173 to $101 \mathrm{mg} / \mathrm{l}$, respectively in March. In April, the concentration of $\mathrm{HCO}_{3}{ }^{-}$and $\mathrm{Ca}^{2+}$ decreased from 554 to 331 and from 170 to $98 \mathrm{mg} / \mathrm{l}$, respectively (Fig. 6). The concentrations of the other major ions did not change significantly along the flow path $\left(\mathrm{Cl}^{-}(147-153 \mathrm{mg} / \mathrm{l}), \mathrm{Mg}^{2+}(58-58 \mathrm{mg} / \mathrm{l}), \mathrm{Na}^{+}(119-128 \mathrm{mg} / \mathrm{l})\right.$ and $\left.\mathrm{K}^{+}(17-19 \mathrm{mg} / \mathrm{l})\right)$ according to the widely spaced measurements (at 0,50 and $400 \mathrm{~m}$ ) (Table 2).

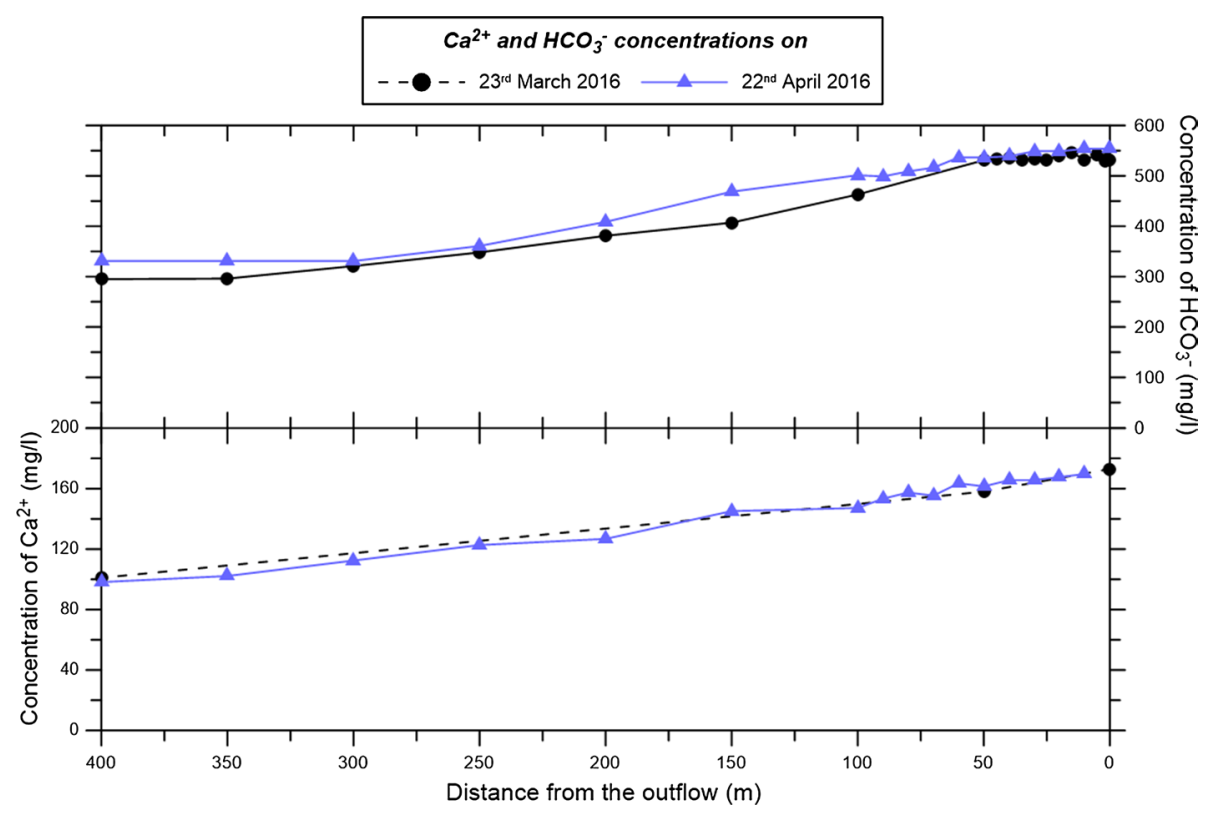

Fig. 6 Variations in the concentrations of $\mathrm{Ca}^{2+}$ and $\mathrm{HCO}_{3}{ }^{-}$along the flow path (error of measurements for both ions: $2 \%$ ) 
Table 2 Concentrations of the major ions at 0, 50 and $400 \mathrm{~m}$ in April (error of measurements: 2\%, for $\left.\mathrm{SO}_{4}{ }^{2-}: 5 \%\right)$

\begin{tabular}{lllllll}
\hline $\begin{array}{l}\text { Distance from } \\
\text { the outflow }(\mathrm{m})\end{array}$ & $\mathrm{SO}_{4}{ }^{2-}(\mathrm{mg} / \mathrm{l})$ & $\mathrm{Cl}^{-}(\mathrm{mg} / \mathrm{l})$ & $\mathrm{Ca}^{2+}(\mathrm{mg} / \mathrm{l})$ & $\mathrm{Mg}^{2+}(\mathrm{mg} / \mathrm{l})$ & $\mathrm{Na}^{+}(\mathrm{mg} / \mathrm{l})$ & $\mathrm{K}^{+}(\mathrm{mg} / \mathrm{l})$ \\
\hline 0 & 353 & 147 & 173 & 58 & 119 & 17 \\
50 & 295 & 147 & 158 & 58 & 121 & 17 \\
400 & 336 & 153 & 101 & 58 & 128 & 19 \\
\hline
\end{tabular}

\section{2 ${ }^{226} \mathrm{Ra}$ and ${ }^{222} \mathrm{Rn}$ Activity}

The concentration of ${ }^{226} \mathrm{Ra}$ in the water (mean value: $351 \mathrm{mBq} / \mathrm{l}$ ) remained the same along the flow path within the error of analysis (Fig. 7).

The ${ }^{222} \mathrm{Rn}$ activity decreased from $167 \pm 9$ to $3 \pm 2 \mathrm{~Bq} / \mathrm{l}$ (between the pit and the 400 metre point) with an increase at $20 \mathrm{~m}$ in April. It dropped to the level of the background radiation (2-3 Bq/1) at $100 \mathrm{~m}$ (Fig. 7).

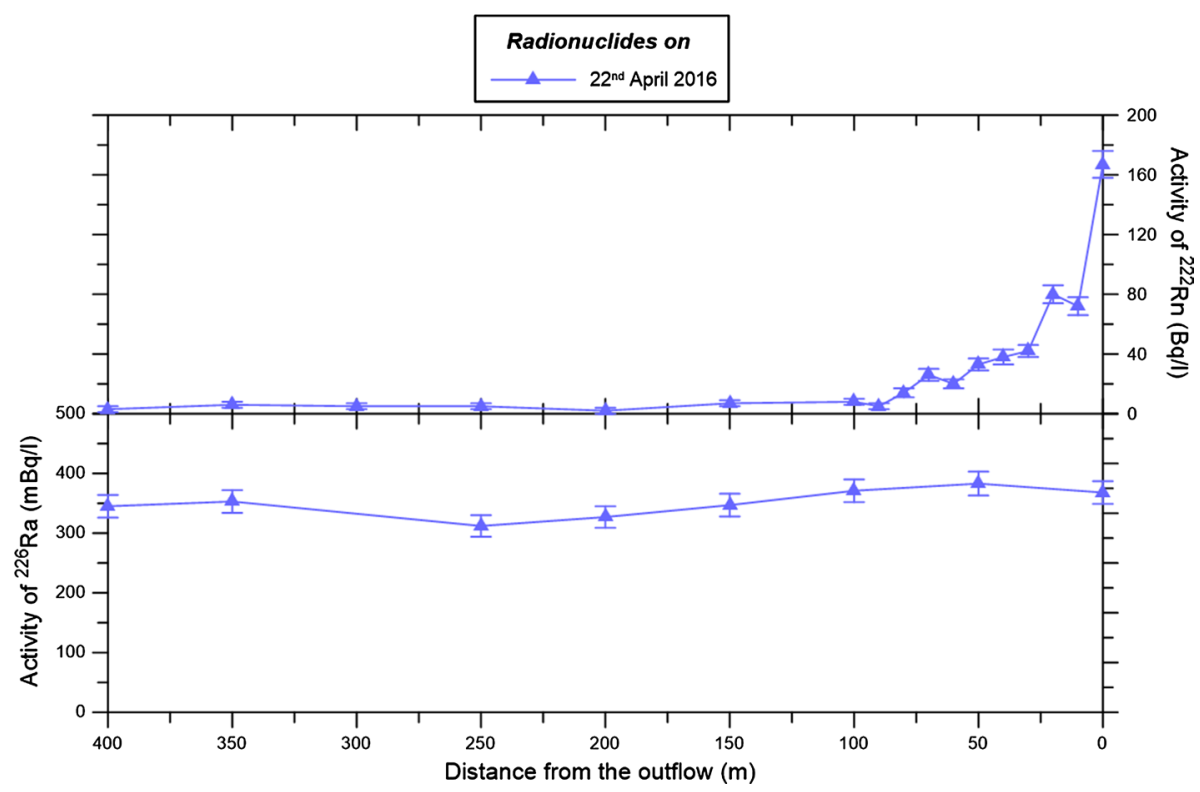

Fig. 7 Variations in the activity of ${ }^{226} \mathrm{Ra}$ and ${ }^{222} \mathrm{Rn}$ along the flow path 


\subsection{Trace Elements}

The concentration of trace elements in the original (unfiltered) samples and in the suspended solid (= unfiltered-filtered) are depicted in Fig. 8. $\mathrm{Be}, \mathrm{Bi}, \mathrm{Cd}, \mathrm{Cr}, \mathrm{Hg}, \mathrm{Mo}, \mathrm{Pb}, \mathrm{Sb}$, Sn, Te, Th, Tl, U, V and Y were present at the lowest concentration in both the unfiltered samples and in the suspension, between 0 and $0.5 \mu \mathrm{g} / \mathrm{l}$ (Fig. 8a). Bi, $\mathrm{Cr}$ and Th were below the detection threshold in the filtered samples. The concentrations of $\mathrm{Al}, \mathrm{As}, \mathrm{Cu}, \mathrm{P}, \mathrm{Sc}, \mathrm{Se}$, Ti and $\mathrm{Zn}$ fell within the range of 1-12 $\mu \mathrm{g} / \mathrm{l}$ (Fig. 8b), while Ba, B, Br, Cs, Fe, I, Li, Mn and $\mathrm{Rb}$ were between 10 and $620 \mu \mathrm{g} / \mathrm{l}$ (Fig. 8c). The concentration of $\mathrm{S}$ and $\mathrm{Si}$ were the highest (4000-55,000 $\mu \mathrm{g} / \mathrm{l})$ in both the unfiltered samples and in the suspension (Fig. 8d).

In the case of many elements $(\mathrm{Be}, \mathrm{Bi}, \mathrm{Cd}, \mathrm{Cr}, \mathrm{Pb}, \mathrm{Th}, \mathrm{Tl}, \mathrm{V}, \mathrm{Y}, \mathrm{Al}, \mathrm{Cu}, \mathrm{Se}, \mathrm{Ti}, \mathrm{Zn}, \mathrm{Fe}$, $\mathrm{Mn}$ ), the concentration in the suspension is close to the total concentration. Other elements like Mo, U, As, P, B, Li, S are represented in relatively less abundance in the suspended solid (Fig. 8).
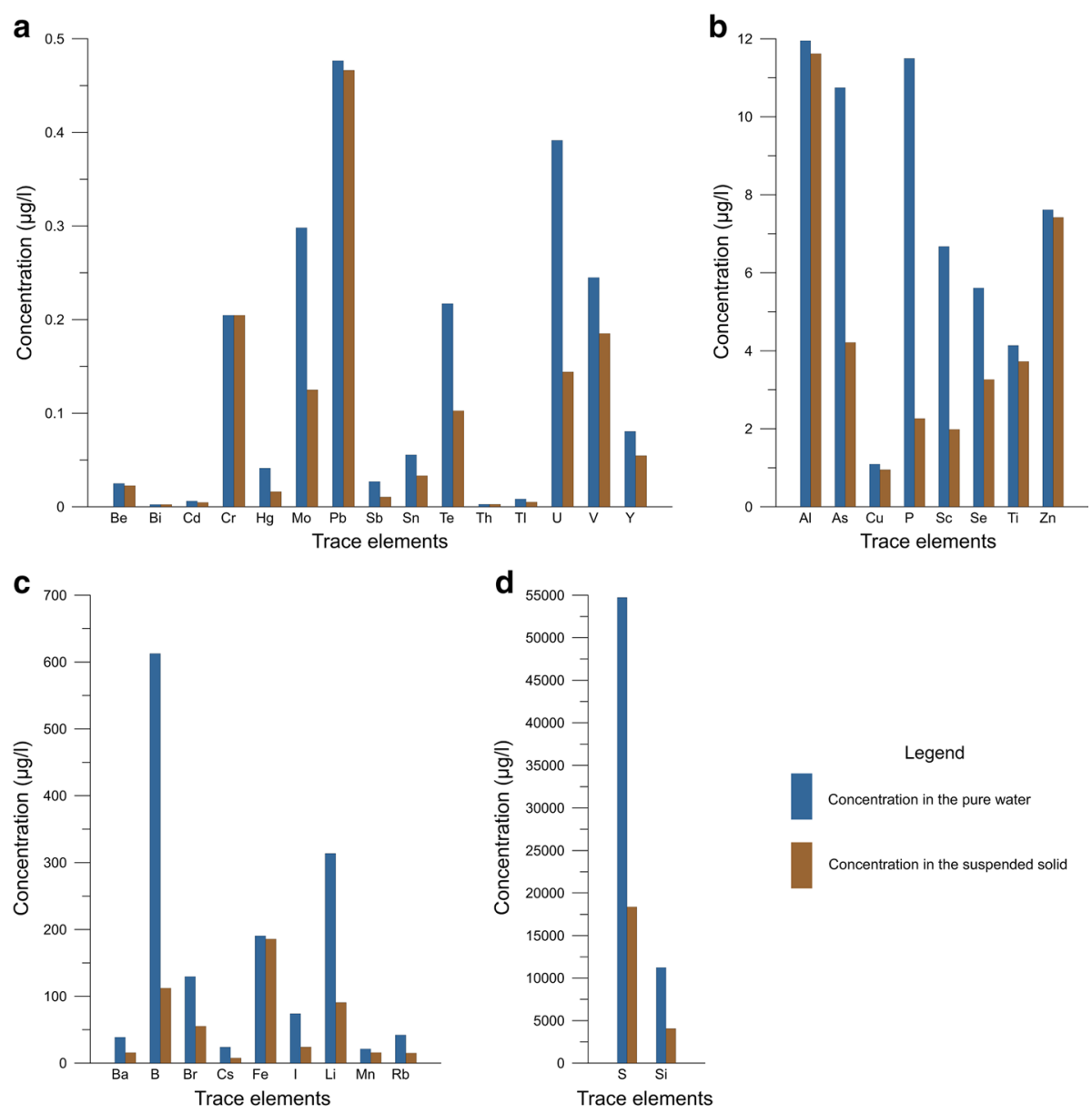

Fig. 8 Trace element concentrations in unfiltered water and in the suspended solid of the pit in the range of a $0-0.5$, b $1-12$, c $10-620$, d 4000-55,000 $\mu \mathrm{g} / \mathrm{l}$ 


\subsection{Simulated $\mathrm{SI}_{\text {calcite }}$ and $\mathrm{p}_{\mathrm{CO} 2}$ and Reactive Transport Modelling}

The saturation index with respect to calcite was modelled using the measured concentrations and parameters. The indices were positive along the whole flow path. The indices increased over the first $80 \mathrm{~m}(0.4-1.55)$, then the values were almost the same between 80 and $150 \mathrm{~m}$ (around 1.55), and decreased from 1.55 to 1.35 in the next $50 \mathrm{~m}(150-200 \mathrm{~m})$, then remained around 1.35 (Fig. 9).

The partial pressure of $\mathrm{CO}_{2}\left(\mathrm{p}_{\mathrm{CO} 2}\right)$ changed in the opposite direction to $\mathrm{SI}_{\text {calcite. }}$. It steeply decreased in the first $100 \mathrm{~m}$, then, increased slightly in the next $100 \mathrm{~m}(100-200 \mathrm{~m})$, and slightly decreased between 200 and 400 m (Fig. 9).

The reactive transport model was fitted to the measured data using a model optimization software, PEST (Watermark Numerical Computing 2016), by adjusting the gas exchange rate constants for $\mathrm{CO}_{2}, \mathrm{O}_{2}$ and ${ }^{222} \mathrm{Rn}\left(k_{\mathrm{CO} 2}, k_{\mathrm{O} 2}, k_{\mathrm{Rn}}\right)$ and the surface area over volume parameter $(\mathrm{A} / \mathrm{V})$ in the rate expression of calcite. While $k_{\mathrm{O} 2}$ and $k_{\mathrm{Rn}}$ could be fitted to the data independently, it was found during trial runs that the value of $k_{\mathrm{CO} 2}$ correlated to the value of $\mathrm{A} / \mathrm{V}$ in the expression of the rate for calcite precipitation. It was found that because of this dependence, a better fit of the measured $\mathrm{pH}$ values, which are very sensitive to the value of $k_{\mathrm{CO} 2}$, could only be obtained at the expense of a worse fit of the $\mathrm{Ca}^{2+}$ and $\mathrm{HCO}_{3}{ }^{-}$concentrations.

Flow and solute transport were modelled using the following form of the advection-dispersion equation, Eq. (2):

$$
\frac{\partial m}{\partial t}=-v \frac{\partial m}{d x}+D_{L} \frac{\partial^{2} m}{d x^{2}}+r
$$

where $m$ is the aqueous concentration (M), $t$ is time (s), $v$ is the water flow velocity $(\mathrm{m} / \mathrm{s}), x$ is the distance from the outflowing $(\mathrm{m})$, and $D_{L}$ is the hydrodynamic dispersion coefficient, which is defined as $D_{L}=\alpha_{L} v+D_{e}\left(\mathrm{~m}^{2} / \mathrm{s}\right)$, where $\alpha_{L}$ is the dispersivity (m) and $D_{e}$ is the diffusion coefficient $\left(\mathrm{m}^{2} / \mathrm{s}\right)$.

The value of $v$ was derived from the discharge rates measured in the course of the experiment. For $D_{e}$, a value of $5 \times 10^{-9} \mathrm{~m} / \mathrm{s}^{2}$ was assumed, and $\alpha_{L}$ was set to $0.05 \mathrm{~m}$. No further optimization of these parameters was attempted, as a good fit between the modelled and measured ${ }^{222} \mathrm{Rn}$ could be obtained with these chosen values (Fig. 11). Since ${ }^{222} \mathrm{Rn}$ is chemically inert, this was considered to be confirmation of the model's ability to simulate the flow and mixing processes within the canal.

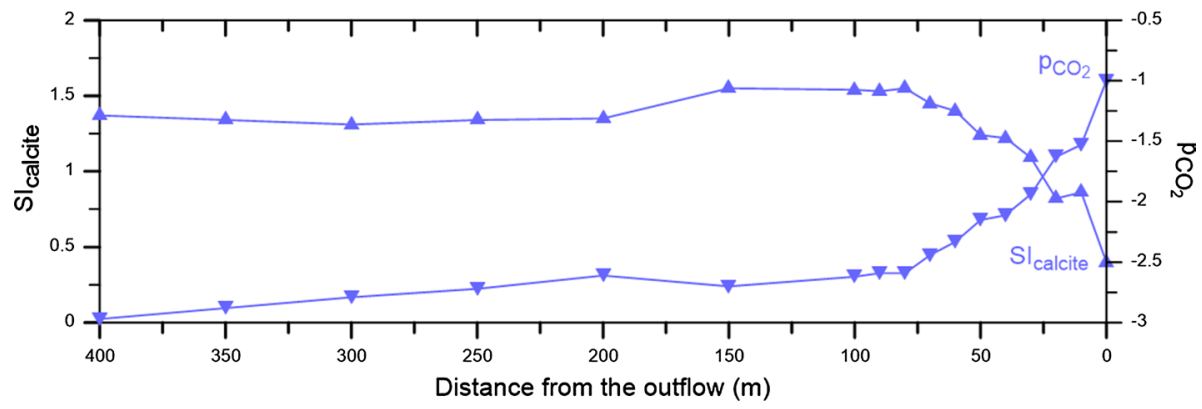

Fig. 9 Modelled variations in $\mathrm{SI}_{\text {calcite }}$ and $\mathrm{p}_{\mathrm{CO} 2}$ along the flow path 


\subsection{Observation of Evolved Precipitates}

Due to 6 weeks of thermal water flowing, reddish-brown, amorphous precipitate formed close to the outflow and up to distance of $15 \mathrm{~m}$ from it (Fig. 10a). Low-magnification SEM images showed extended bacterial colonization, with some minerals in the first 15-m-long section (Fig. 10b). The high-resolution SEM images reflected the networked structures and morphological variability of the biofilm-forming bacterial cells. Different sized and shaped filamentous bacteria in interwoven form (red arrow), numerous straight (yellow arrow) and curved rod-shaped (blue arrow), aggregate-forming cells of varied sizes (green arrow) were visible in the photos. The rod-shaped cells form long chains (purple arrow) (Fig. 10c).

Downstream, a beige, crystalline precipitate evolved along to the end of the studied section (Fig. 10d). Calcite crystals (also revealed by XRD) dominate this precipitate with serrated mineral surfaces. In the low-magnification SEM images, patches of bacterial
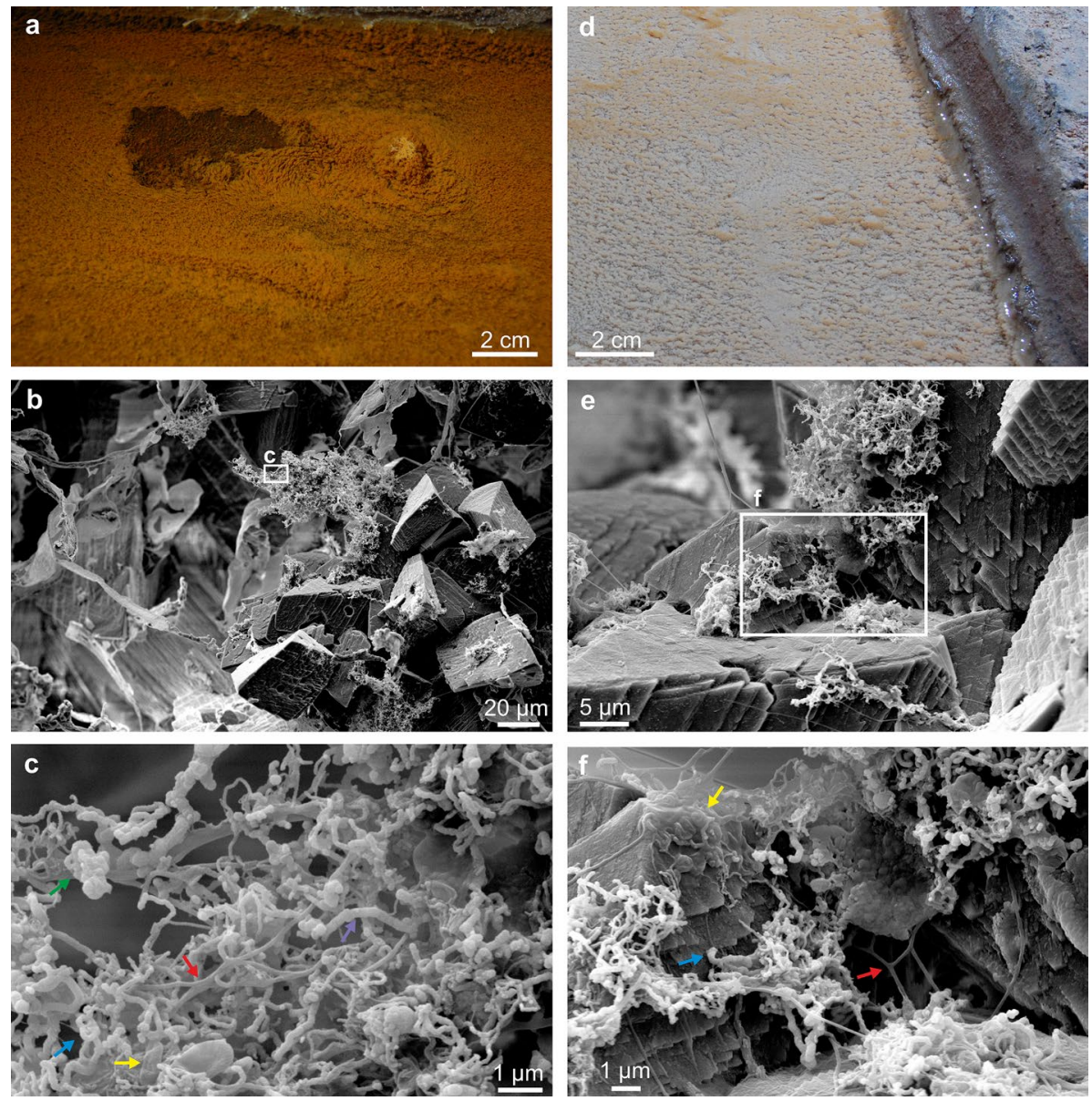

Fig. 10 The reddish-brown, amorphous precipitate at $8 \mathrm{~m}$ a on site, b, $\mathbf{c}$ in SEM images; crystalline precipitate at $40 \mathrm{~m} \mathbf{d}$ on site, $\mathbf{e}, \mathbf{f}$ in SEM images 
colonization can be seen (Fig. 10e). The morphology of bacteria of these colonizations is the same as in the biofilms of the first $15 \mathrm{~m}$ (Fig. 10f).

\section{Interpretation and Discussion}

Thermal springs are discharge features of regional groundwater flow systems and are characterized by a near-constant volume discharge and relatively invariant physicochemical parameters at the outflow as long as the hydrogeological environment is stable (for hundreds or thousands of years) (Goldscheider et al. 2010; Mádl-Szőnyi and Tóth 2015). The natural thermal water discharge can be simulated by invariable pumping from a well. Though the initial discharge is stable, volume discharge could change along the flow path due to the roughness and route of the bed, even in regular channels, like that in the experiment.

\subsection{Physicochemical Parameter Changes Along the Flow Path}

The air temperature of the tunnel is affected by ventilation, but this fact does not necessarily influence the temperature of the water inside the tunnel if the temperature of the water and the air are similar, as was the case in the present study. This supposition was then confirmed by the absence of significant correlation $(-0.27$ ) (Table 3 ).

The abrupt pressure drop at the outflow results in rapid, intensive $\mathrm{CO}_{2}$ degassing and a concomitant sharp rise in $\mathrm{pH}$ values close to the outflow, with less intensive degassing as the volume of $\mathrm{CO}_{2}$ in the water decreases.

The strong significant negative correlation (-0.94) (Table 3) demonstrates the converse nature of the change in dissolved oxygen content from $\mathrm{p}_{\mathrm{CO} 2}$, as $\mathrm{O}_{2}$ originating in the air of the tunnel dissolves into the water. After reaching saturation point, the dissolved oxygen content remains stable (Fig. 5).

Given the increase in the $\mathrm{pH}$ of the water, supersaturation and the precipitation of $\mathrm{CaCO}_{3}$ are to be expected, and this assumption gains support from the increase of $\mathrm{SI}_{\text {calcite }}$ (Fig. 9), the decrease in specific electric conductivity (Fig. 5) and the decrease in the concentration of the two major ions, $\mathrm{Ca}^{2+}$ and $\mathrm{HCO}_{3}^{-}$(Fig. 6). The significant correlation coefficients of 0.98 and $0.90-0.92$ obtained between the specific electric conductivity and the concentrations of $\mathrm{Ca}^{2+}$ and $\mathrm{HCO}_{3}{ }^{-}$, respectively, confirm that the decrease in these two ions causes the drop in specific electric conductivity. The concentration of $\mathrm{Ca}^{2+}$ and $\mathrm{HCO}_{3}{ }^{-}$displayed a continual decrease along the flow path.

From the relatively spaced-out measurements, it seems that the concentration of other major ions $\left(\mathrm{Mg}^{2+}, \mathrm{Na}^{+}, \mathrm{K}^{+}, \mathrm{Cl}^{-}\right)$remains relatively constant along the flow path (Table 2); this is related to the fact that they do not take part in precipitation processes. Though $\mathrm{Mg}-$ calcite has been determined as the main mineral phase of the carbonates in the spring caves of the BTK (Eróss 2010), along the flow path a decrease in $\mathrm{Mg}^{2+}$ in the water was not detectable.

\subsection{Radionuclides and Trace Elements in the Water}

The concentration of ${ }^{226} \mathrm{Ra}$ remains stable (Fig. 8a) in the canal, displaying no significant correlation with any of the parameters (Table 3). ${ }^{222} \mathrm{Rn}$ is the decay product of ${ }^{226} \mathrm{Ra}$, and it degasses rapidly from water, since there is no additional supply along the flow path. The 


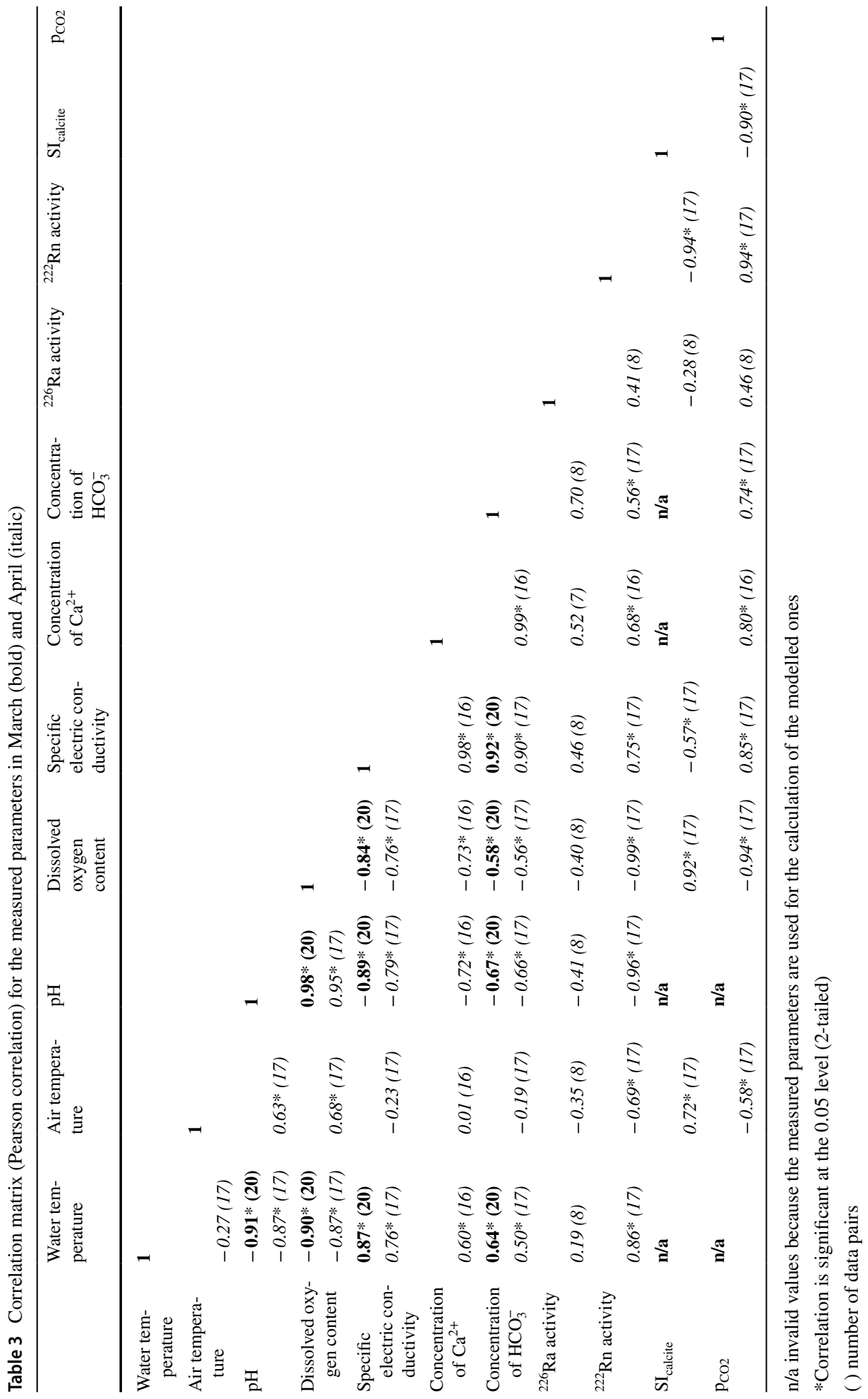


${ }^{222} \mathrm{Rn}$ activity displays a strong significant correlation with $\mathrm{p}_{\mathrm{CO} 2}(0.94)$ and a strong significant negative correlation with $\mathrm{pH}(-0.96)$ and dissolved oxygen content $(-0.99)$ (Table 3$)$. The strong correlation with $\mathrm{p}_{\mathrm{CO} 2}$ demonstrates that ${ }^{222} \mathrm{Rn}$ degasses in a way similar to $\mathrm{CO}_{2}$, as it is also a dissolved gas: its concentration dropped to the level of the background radiation within the first $100 \mathrm{~m}$ (Fig. 7). The high surface-to-volume-ratio of the water flowing in the canal also promotes the processes of degassing and ingassing.

Erôss (2010) found that $\mathrm{Ca}$, together with smaller amounts of $\mathrm{Si}, \mathrm{Mg}, \mathrm{Fe}$ and $\mathrm{Al}$, was a main element in the build-up of biofilms in the spring caves in Gellért Hill. In a comprehensive study of the water in spring caves of BTK, S and Sr were found to have the highest concentrations (10-34.5 and 0.705-3.1 $\mu \mathrm{g} / \mathrm{l}$, respectively) among the trace elements (Dobosy et al. 2016). In agreement with these findings, in this study, S and Si were the main trace elements both in the water and in the suspended solid (Fig. 8d). Al, Be, Cd, Cr, $\mathrm{Cu}, \mathrm{Fe}, \mathrm{Mn}, \mathrm{Pb}$, Ti and $\mathrm{Zn}$ prefer the suspension form in the pit (Fig. 8). These elements were found to be in high concentrations in precipitates in the BTK (Dobosy et al. 2016; Erôss 2010). This observation can be explained by the hydrolysis of the metal ions and their subsequent precipitation as hydroxides. Except for $\mathrm{Li}$, these elements are abundant in the dissolved phase form of soluble oxoanions (e.g. $\mathrm{UO}_{2}{ }^{2+}, \mathrm{PO}_{4}{ }^{3-}$, etc.). Thus, the distribution of the trace elements between dissolved and suspended matter can be accounted for.

\subsection{Comparison of the Measured and Modelled Variations of the Parameters}

The simulated values for dissolved oxygen and ${ }^{222} \mathrm{Rn}$ activity derived from the reactive transport model are in good agreement with the measured values for both the March and April experiments (Fig. 11). The $\mathrm{pH}$ values and $\mathrm{HCO}_{3}{ }^{-}$concentrations, on the other hand,
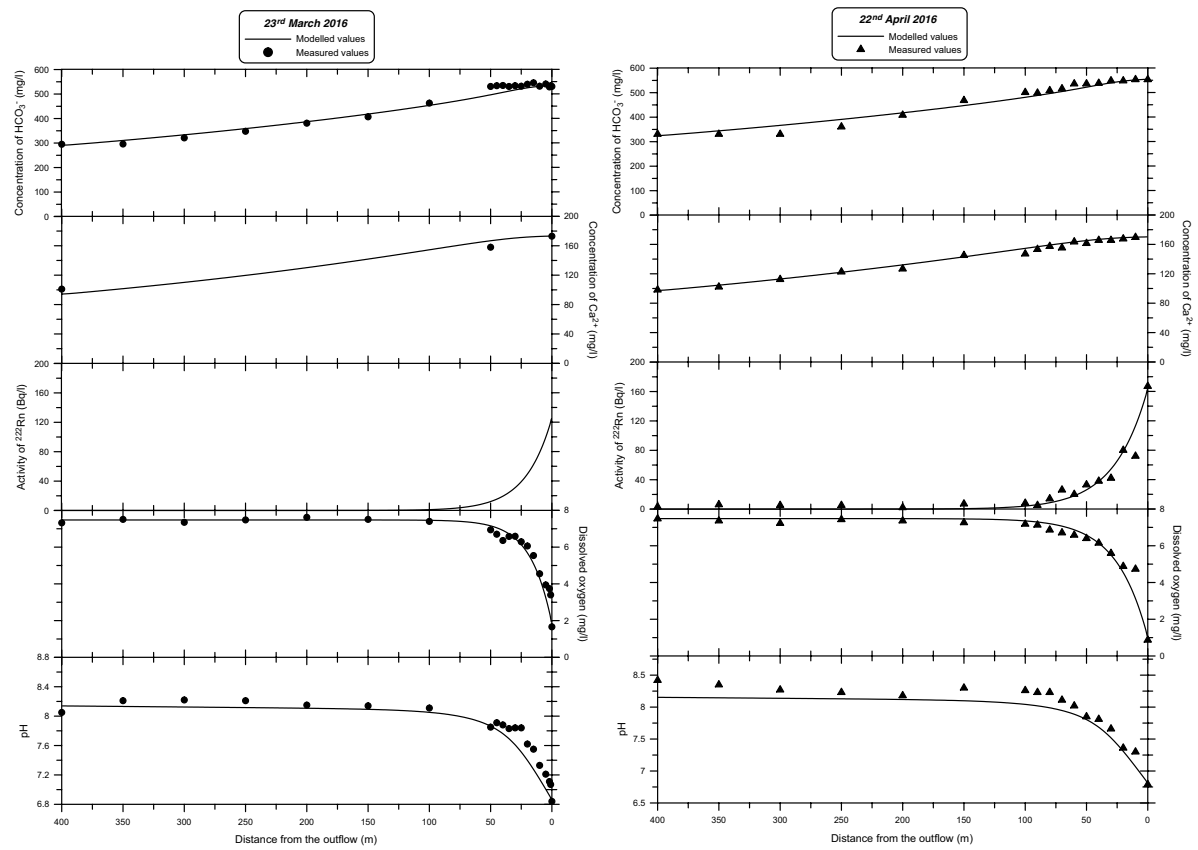

Fig. 11 The measured and modelled variations of $\mathrm{pH}$, dissolved oxygen, ${ }^{222} \mathrm{Rn}$ activity, and $\mathrm{Ca}^{2+}$ and $\mathrm{HCO}_{3}{ }^{-}$concentrations along the flow path 
do not match those of the model to such a degree. The March and April data show little change in the measured $\mathrm{HCO}_{3}{ }^{-}$concentration over the first $50 \mathrm{~m}$ of the canal, whereas in the model, $\mathrm{HCO}_{3}{ }^{-}$concentrations decrease almost immediately. For $\mathrm{Ca}^{2+}$, the opposite appears to be the case: the measured concentrations show an almost linear decrease starting immediately, albeit there is a wide scatter of the data points in April, while the modelled $\mathrm{Ca}^{2+}$ decrease along the canal seems to be slow initially, becoming progressively faster further downstream. The model consistently underestimates $\mathrm{pH}$. Obtaining a better fit of the $\mathrm{pH}$ by using a faster $\mathrm{CO}_{2}$ degassing rate only worsened the fit for $\mathrm{Ca}^{2+}$. Finally, from the measurements, it appears that the decrease in $\mathrm{HCO}_{3}{ }^{-}$stabilizes after $300-350 \mathrm{~m}$, and this is more clearly apparent in the April data. While the model similarly predicts a lower rate of decrease with downstream distance, the change in the simulated concentration-versusdistance curve is much more gradual, and not as pronounced as for the measured concentrations (Fig. 11).

\subsection{Indirect and Direct Indications and Evidences for Biological and Carbonate Precipitation}

According to Eq. (3), one mole of $\mathrm{Ca}^{2+}$ reacts with two equivalent alkalinity (indicated as $\mathrm{HCO}_{3}{ }^{-}$), so the stoichiometric ratio of $\mathrm{Ca}$ /alkalinity is 1:2 [Eq. (3)]. The blue line in Fig. 12 shows this ratio.

$$
2 \mathrm{HCO}_{3}^{-}+\mathrm{Ca}^{2+} \rightarrow \mathrm{CaCO}_{3}+2 \mathrm{H}^{+}
$$

The variations in the concentrations of the two major ions show that the ratio changes in the way described by Eq. (3) until $150 \mathrm{~m}$ from the outflow. After $150 \mathrm{~m}, \mathrm{less}_{\mathrm{HCO}_{3}}{ }^{-}$or more $\mathrm{Ca}^{2+}$ leaves the water (Fig. 12), what is consumed in calcite precipitation.

The variations in the concentrations of major ions and specific electric conductivity, the measured $\mathrm{Ca}$ /alkalinity ratio and the simulations refer to continuous calcium carbonate precipitation along the flow path. The stoichiometric ratio of $\mathrm{Ca}$ /alkalinity of the measured major ions and the reactive transport model shows adverse $\mathrm{HCO}_{3}{ }^{-}$concentration compared to the equation and simulated values. It suggests that after $150 \mathrm{~m}$ from the outflow, besides $\mathrm{CaCO}_{3}$ precipitation, the simulated gas exchange, namely $\mathrm{CO}_{2}$ degassing decreases the dissolved $\mathrm{HCO}_{3}{ }^{-}$concentration. However, another process is supposed to further reduce it. A possible explanation is the roughness/shallowing of the canal bed (Hammer et al. 2008).

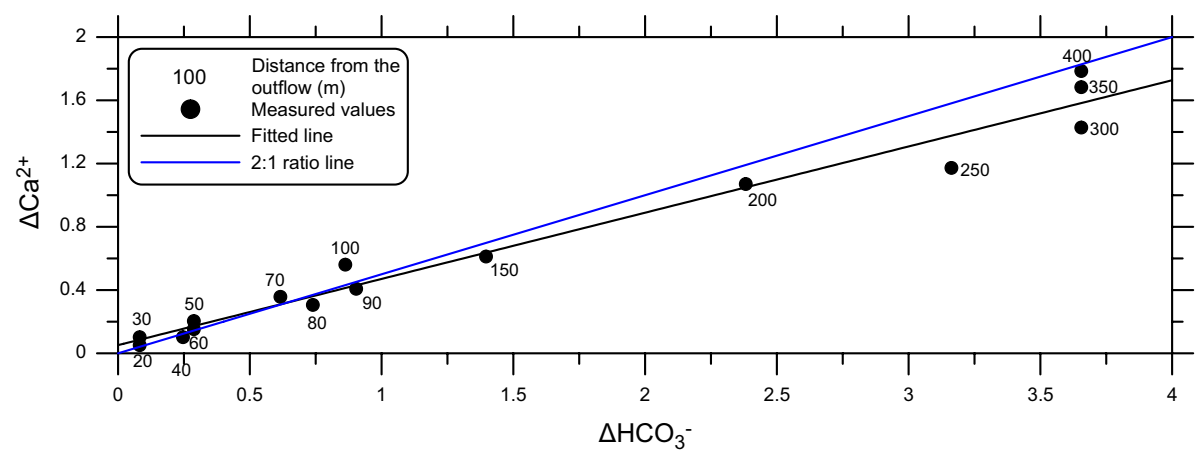

Fig. 12 Changes in $\mathrm{Ca}^{2+}$ and $\mathrm{HCO}_{3}{ }^{-}$along the flow path 
The afore-mentioned changes of physicochemical parameters are the results of the oneday-long experiments, when thermal water was pumped into the canal, where no precipitates were to be found. Though there are indications of $\mathrm{CaCO}_{3}$ precipitation, carbonates could not be observed in the canal after 1 day. Bacteria arriving with the thermal water also could not form any biofilm during the limited duration of the experiment. Consequently, the effects of the precipitates could not be examined in this part of the study.

The increase in $\mathrm{pH}$ and the decrease in the concentration of $\mathrm{Ca}^{2+}$ and $\mathrm{HCO}_{3}{ }^{-}$can be observed along the flow path in travertine-depositing streams and springs (Amundson and Kelly 1987; Dandurand et al. 1982; Herman and Lorah 1986, 1987; Hoffer-French and Herman 1989, 1990; Lorah and Herman 1988, 1990; Nordstrom et al. 2005 etc.). In many cases, physical evidence (e.g. travertines) for calcite precipitation are to be seen in springs, where the streambed is steep and especially around waterfalls (Chen et al. 2004; Zhang et al. 2001). In such places, calcite supersaturation by at least a factor of five is required for calcite precipitation (Hoffer-French and Herman 1989, 1990; Jacobson and Usdowski 1975; Lorah and Herman 1988, 1990).

According to the observations of the formed precipitates during the six-weeks-long experiment, there is continuous precipitation along the flow path, dominated by bacteria close to the outflow and by calcite further downstream. The change from the organic to the inorganic precipitate is to be found in the abruptly changing section of physicochemical parameters. The appearance of the reddish-brown biofilm is consistent with the field observations, that biofilms are forming at the mixing of reduced thermal water and oxidative air (Borsodi et al. 2012; Erôss et al. 2012; Mádl-Szőnyi and Erőss 2013; Mádl-Szőnyi et al. 2017a). The reddish-brown colour is the usual colour of biofilms in the BTK, caused by $\mathrm{Fe}(\mathrm{III})$, refers to the presence of iron(FeII)-oxidizing bacteria (Anda et al. 2014, 2015; Borsodi et al. 2012).

In the experimental canal, from $15 \mathrm{~m}$ downstream, calcite precipitates, also the parameters became stable. At the beginning of this section, $\mathrm{SI}_{\text {calcite }}$ is $0.82-0.86$, which means that this rate of supersaturation is required for calcite precipitation under the circumstances of the experiment. Inorganic processes seem to control the precipitation and they suppress organic ones after $15 \mathrm{~m}$ from the outflow. It was revealed by SEM images, where patches of biofilms can be seen on the surfaces of calcite crystals.

It seems that in the scale and time period of the measurements and observations, there is no evidence for the effect of bacteria on calcite precipitation and changes of aquatic chemistry. The study of the interrelationships between water chemistry and the precipitates needs longer time scale, which was not part of this study.

\section{Conclusions and Summary}

Springs display changes in their physicochemical parameters from their discharge along their flow path. The main driving force of these changes is the pressure drop, resulted in $\mathrm{CO}_{2}$ degassing. The variations have a direct effect on the formation of organic and inorganic precipitates. The complexity of natural spring systems and the limitations of laboratory experiments make it difficult to understand all the governing factors. In situ experiments, integrated with reactive transport modelling, provide a useful tool to monitor the physicochemical parameters and to better understand the background processes.

The in situ experimental study, carried out in the canal of the Gellért tunnel, BTK, was conducted to simulate thermal spring discharge into a warm-air cave. It was found that the 
main driving forces of the physicochemical parameter changes along the flow path are $\mathrm{CO}_{2}$ degassing and in this context, calcite precipitation. The latter had no physical evidence after the one-day-long experiment, only indirect indications, namely the gradual decrease in specific electric conductivity, $\mathrm{Ca}^{2+}$ and $\mathrm{HCO}_{3}{ }^{-}$concentrations and increase in $\mathrm{pH}$ and $\mathrm{SI}_{\text {calcite }}$.

Due to the high gradient between the air and the water, the changes are fast and occur in the first $100 \mathrm{~m}$ from the outflow. The temperature difference between water and air temperatures is a less influential factor in the changes in the parameters and $\mathrm{SI}_{\text {calcite }}$. The dissolving of oxygen from the air into the water and the degassing of ${ }^{222} \mathrm{Rn}$ are controlled by pure chemical reactions, as was also confirmed by reactive transport model. Besides the modelled $\mathrm{CO}_{2}$ degassing and calcite precipitation, another process influences $\mathrm{pH}$ and the concentration of $\mathrm{HCO}_{3}{ }^{-}$, which is probably the roughness of the stream bed. In the scale and time period of the in situ experiments, the effect of bacteria and calcite precipitation could not be detected.

In the absence of organic and inorganic precipitates, most of the trace elements which are usually adsorbed by biofilm occurring in the natural spring caves of the BTK were present in the form of suspended solids in the water, a fact which seems to be related to early precipitation processes. The activity of ${ }^{226} \mathrm{Ra}$ in the water remained stable along the flow path in the lack of adsorbing precipitates.

The presence of bacteria in the form of biofilm close to the outflow was observed after 6 weeks of the flow of the same thermal water as used in the experiment. The appropriate circumstances for bacteria forming biofilm are where thermal water discharges and interacts with the oxidative air. Reddish-brown colour reflects the presence of iron(FeII)-oxidizing bacteria.

In the circumstances of the experiment, supersaturation levels of $0.82-0.86$ with respect to calcite proved to be sufficient for precipitation. The key to the change from biological to chemical precipitates is to be found in the abruptly changing section of physicochemical parameters. The precipitation of calcite continued after the parameters became stable. Further downstream inorganic processes suppress microbiological life, and bacterial colonization could be observed only patchily on the surface of calcite crystals.

This study was able to demonstrate that a method integrating experimental study and numerical modelling is a suitable approach in the quest to better understand precipitation processes around thermal springs.

Acknowledgements This work was supported by the National Research Development and Innovation Office (NKFIH 101356). The authors would like to thank the permission and the help of Budapest Spa Plc. and the management of Gellért Spa. The measurements would not have been possible without the assistance of the Geology B.Sc, M.Sc and Ph.D. students of Eötvös Loránd University. The scientific discussions with Andrea Mindszenty are highly appreciated. Both in the field and in the laboratory, László Szikszay has provided essential help. Thanks are also due to the Departments of Nuclear Physics, Microbiology, Physical Geography, Meteorology, Analytical Chemistry and the Imre Müller and Heinz Surbeck Hydrogeology Laboratory of Eötvös Loránd University for the various measurements which were required. Special thanks to Heinz Surbeck for providing the alpha spectrometer to measure the radionuclides. Thanks also to András Hegedús and Katalin Csondor for their professional work on the photos.

Open Access This article is distributed under the terms of the Creative Commons Attribution 4.0 International License (http://creativecommons.org/licenses/by/4.0/), which permits unrestricted use, distribution, and reproduction in any medium, provided you give appropriate credit to the original author(s) and the source, provide a link to the Creative Commons license, and indicate if changes were made. 


\section{References}

Alföldi L, Bélteky L, Böcker T, Horváth J, Korim K, Rémi R (eds) (1968) Budapest hévizei (Thermal waters of Budapest) [in Hungarian]. Hungarian Institute for Water Resources Research Budapest, Budapest

Amundson R, Kelly E (1987) The chemistry and mineralogy of a $\mathrm{CO}_{2}$-rich travertine depositing spring in the California Coast Range. Geochim Cosmochim Acta 51:2883-2890. https://doi.org/10.1016/00167037(87)90364-4

Anda D, Büki G, Krett G, Makk J, Márialigeti K, Erőss A, Mádl-Szőnyi J, Borsodi AK (2014) Diversity and Morphological structure of bacterial communities inhabiting the Diana-Hygieia thermal spring (Budapest, Hungary). Acta Microbiol Immunol Hun 61(3):329-346. https://doi.org/10.1556/AMicr 61.2014.3.7

Anda D, Makk J, Krett G, Jurecska L, Márialigeti K, Mádl-Szőnyi J, Borsodi AK (2015) Thermophilic prokaryotic communities inhabiting the biofilm and well water of a thermal karst system located in Budapest (Hungary). Extremophiles 19(4):787-797. https://doi.org/10.1007/s00792-015-0754-1

Borsodi AK, Knáb M, Krett G, Makk J, Márialigeti K, Erőss A, Mádl-Szőnyi J (2012) Biofilm Bacterial Communities Inhabiting the Cave Walls of the Buda Thermal Karst System, Hungary. Geomicrobiol J 29(7):611-627. https://doi.org/10.1080/01490451.2011.602801

Chen J, Zhang DD, Wang S, Xiao T, Huang R (2004) Factors controlling tufa deposition in natural waters at waterfall sites. Sediment Geol 166:353-366. https://doi.org/10.1016/j.sedgeo.2004.02.003

Dandurand JL, Gout R, Hoefs J, Menschel G, Schott J, Usdowski E (1982) Kinetically controlled variations of major components and carbon and oxygen isotopes in a calcite-precipitating spring. Chem Geol 36:299-315. https://doi.org/10.1016/0009-2541(82)90053-5

Das S, Mohanti M (2015) The geochemistry of tufa-depositing stream waters of Bhaliadal, Mayurbhanj District (Odisha), India. Vistas Geol Res Spec Publ Geol 13:141-151

Dobosy P, Sávoly Z, Óvári M, Mádl-Szőnyi J, Záray Gy (2016) Microchemical characterization of biogeochemical samples collected from the Buda Thermal Karst Sytem, Hungary. Microchem J 124:116-120. https://doi.org/10.1016/j.microc.2015.08.004

Dreybrodt W, Buhmann D, Michaelis J, Usdowski E (1992) Geochemically controlled calcite precipitation by $\mathrm{CO}_{2}$ outgassing: field measurements of precipitation rates in comparison to theoretical predictions. Chem Geol 97:285-294. https://doi.org/10.1016/0009-2541(92)90082-G

Eaton AD, Clesceri LS, Rice EW, Greenberg AE, Franson MAH (eds) (2005) Standard methods for the examination of water and wastewater, 21st edn. American Public Health Association, Washington

Ehrlich HL (2001) Geomicrobiology, 4th edn. Marcel Dekker, New York

Engel AS, Porter ML, Kinkle BK, Kane TC (2001) Ecological assessment and geological significance of microbial communities from Cesspool Cave, Virginia. Geomicrobiol J 18(3):259-274. https://doi. org/10.1080/01490450152467787

Erhardt I, Ötvös V, Erőss A, Czauner B, Simon Sz, Mádl-Szőnyi J (2017) Hydraulic evaluation of the hypogenic karst area in Budapest (Hungary). Hydrogeol J 25(6):1871-1891. https://doi. org/10.1007/s10040-017-1591-3

Erőss A (2010) Characterization of fluids and evaluation of their effects on karst development at the Rózsadomb and Gellért Hill, Buda Thermal Karst, Hungary. Dissertation, Eötvös Loránd University

Erôss A, Mádl-Szőnyi J, Surbeck H, Horváth Á, Goldscheider N, Csoma ÉA (2012) Radionuclides as natural tracers for the characterization of fluids in regional discharge areas, Buda Thermal Karst, Hungary. J Hydrol 426-427:124-137. https://doi.org/10.1016/j.jhydrol.2012.01.031

Fujisawa A, Tazaki K (2003) The radioactive microbial mats-in case of Misasa hot springs in Tottori Prefecture. In: Kamata N (ed) Proceedings: international symposium of the Kanazawa University 21st-century COE Program, vol 1. Kanazawa University, Kanazawa, pp 328-331

Gainon F, Goldscheider N, Surbeck H (2007) Conceptual model for the origin of high radon levels in spring waters-the example of the St. Placidus spring, Grisons, Swiss Alps. Swiss J Geosci 100:251-262. https://doi.org/10.1007/s00015-007-1220-6

Genereux DP, Hemond HF (1992) Determination of gas exchange rate constants for a small stream on Walker Branch Watershed, Tennessee. Water Resour Res 28(9):2365-2374. https://doi. org/10.1029/92WR01083

Goldscheider N, Mádl-Szőnyi J, Erőss A, Schill E (2010) Review: thermal water resources in carbonate rock aquifers. Hydrogeol J 18(6):1303-1318. https://doi.org/10.1007/s10040-010-0611-3

Haas J (2001) Geology of Hungary. Eötvös University Press, Budapest

Hammer $\varnothing$, Dysthe DK, Lelu B, Lund H, Meakin P, Jamtveit B (2008) Calcite precipitation instability under laminar, open-channel flow. Geochim Cosmochim Acta 72:5009-5021. https://doi. org/10.1016/j.gca.2008.07.028 
Herman JS, Lorah MM (1986) Groundwater geochemistry in Warm River Cave, Virginia. NSS Bull 48:54-61

Herman JS, Lorah MM (1987) $\mathrm{CO}_{2}$ outgassing and calcite precipitation in Falling Spring Creek, Virginia, USA. Chem Geol 62:251-262. https://doi.org/10.1016/0009-2541(87)90090-8

Hoffer-French KJ, Herman JS (1989) Evaluation of hydrological and biological influences on $\mathrm{CO}_{2}$ fluxes from a karst stream. J Hydrol 108:189-212. https://doi.org/10.1016/0022-1694(89)90283-7

Hoffer-French KJ, Herman JS (1990) $\mathrm{A} \mathrm{CO}_{2}$ outgassing model for Falling Spring Run, Augusta County, Virginia. In: Herman JS, Hubbard A Jr (eds) Travertine-marl: stream deposits in Virginia, vol 101. Virginia Div Mineral Res Publ, pp 17-32

Jacobson RL, Usdowski E (1975) Geochemical controls on a calcite precipitating spring. Contrib Mineral Petrol 51:65-74. https://doi.org/10.1007/BF00403513

Keppel MN, Post VEA, Love AJ, Clarke JDA, Werner AD (2012) Influences on the carbonate hydrochemistry of mound spring environments, Lake Eyre South region, South Australia. Chem Geol 296-297:50-65. https://doi.org/10.1016/j.chemgeo.2011.12.017

Kovács J, Erôss A (2017) Statistically optimal grouping using combined cluster and discriminant analysis (CCDA) on a geochemical database of thermal karst waters in Budapest. Appl Geochem 84:7686. https://doi.org/10.1016/j.apgeochem.2017.05.009

Le Guern C, Baranger P, Crouzet C, Bodénan F, Conil P (2003) Arsenic trapping by iron oxyhydroxides and carbonates at hydrothermal spring outlets. Appl Geochem 18:1313-1323. https://doi.org/10.1016/ S0883-2927(03)00053-2

Lorah MM, Herman JS (1988) The chemical evolution of a travertine-depositing stream: geochemical processes and mass-transfer reactions. Water Resour Res 24(9):1541-1552. https://doi.org/10.1029/ WR024i009p01541

Lorah MM, Herman JS (1990) Geochemical evolution and calcite precipitation rates in Falling Spring Creek, Virginia. In: Herman JS, Hubbard A Jr (eds) Travertine-marl: stream deposits in Virginia, vol 101. Virginia Div Mineral Res Publ, pp 5-17

Mádl-Szőnyi J, Erőss A (2013) Effects of regional groundwater flow on deep carbonate systems focusing on discharge zones. In: Proceedings of the International Symposium on Regional Groundwater Flow: Theory, Applications and Future development, 21-23 June Xi'an, China. China Geological Survey, Commission of Regional Groundwater Flow, IAH, pp 71-75

Mádl-Szőnyi J, Tóth Á (2015) Basin-scale conceptual groundwater flow model for an unconfined and confined thick carbonate region. Hydrogeol J 23(7):1359-1380. https://doi.org/10.1007/s1004 0-015-1274-X

Mádl-Szőnyi J, Leél-Őssy Sz, Kádár M, Angelus B, Zsemle F, Erôss A, Kalinovits S, Segesdi J, Müller I, Mindszenty A (2001) A Budai Termálkarszt-rendszer hidrodinamikájának vizsgálata nyomjelzéssel. (The examination of the hydrodynamic situation of Buda Thermal Karst with tracers) [in Hungarian]. (Report) Budapest, Hungary

Mádl-Szőnyi J, Czauner B, Iván V, Tóth Á, Simon Sz, Erőss A, Bodor P, Havril T, Boncz L, Sőreg L (2017a) Confined carbonates-regional scale hydraulic interaction or isolation? Mar Pet Geol. https:// doi.org/10.1016/j.marpetgeo.2017.06.006

Mádl-Szőnyi J, Erôss A, Tóth Á (2017b) Fluid flow systems and hypogene karst of the Transdanubian Range, Hungary - with special emphasis on Buda Thermal Karst. In: Klimchouk A, Palmer A, De Waele J, Auler A, Audra P (eds) Hypogene Karst Regions and Caves of the World. Springer, Cham. https://doi.org/10.1007/978-3-319-53348-3

Makk J, Tóth E, Anda D, Pál S, Schumann P, Kovács AL, Mádl-Szőnyi J, Márialigeti K, Borsodi AK (2016) Deinococcus budaensis sp. nov., a mesophilic species isolated from biofilm sample of a hydrothermal spring cave. Int J Syst Evol Microbiol 66(12):5345-5351. https://doi.org/10.1099/ijsem.0.001519

Nagai K, Tazaki K, Tanaka Y (2001) Accumulation of arsenic in microbial mats, Masutomi springs, Yamanashi prefecture [in Japanese]. Geosci Rep Shimane Univ 20:179-188

Nordstrom DK, Ball JW, McCleskey RB (2005) Ground water to surface water: chemistry of thermal outflows in Yellowstone National Park. Geotherm Biol Geochem Yellowstone Natl Park 73-94

Parkhurst DL, Appelo CAJ (2013) Description of input and examples for PHREEQC version 3-a computer program for speciation, batch-reaction, one-dimensional transport, and inverse geochemical calculations. U.S. Geological Survey Techniques and Methods, book 6, chap A43

Plummer LN, Wigley TML, Parkhurst DL (1978) The kinetics of calcite dissolution in $\mathrm{CO}_{2}$-water systems at 5 degrees to 60 degrees $\mathrm{C}$ and 0.0 to $1.0 \mathrm{~atm} \mathrm{CO}_{2}$. Am J Sci 278(2):179-216. https://doi. org/10.2475/ajs.278.2.179

Raymond PA, Zappa CJ, Butman D, Bott TL, Potter J, Mulholland P, Laursen AE, McDowell WH, Newbold D (2012) Scaling the gas transfer velocity and hydraulic geometry in streams and small rivers. Limnol Oceanogr Fluid Environ 2(1):41-53. https://doi.org/10.1215/21573689-1597669 
Sarbu SM, Kane TC, Kinkle BK (1996) A chemoautotrophically based cave ecosystem. Science 272(5270):1953-1955. https://doi.org/10.1126/science.272.5270.1953

Schafarzik F (1920) Szökevény hévforrások a Gellérthegy tövében (Springs discharging directly in River Danube) [in Hungarian]. Földt Közl 3:79-158

Somogyi K (2009) A Duna hatása a Gellért-hegy előterében (The effect of River Danube at the foothill of Gellért Hill) [in Hungarian]. MSc Thesis, Eötvös Loránd University

Striczki I (2010) A Duna és a felszín alatti vizek kapcsolatának vizsgálata a budai Dunaparti Főgyújtő csatorna monitoring rendszerébe tartozó kutak, források segítségével (The connection between River Danube and groundwater based on the observation wells and springs of the monitoring network of Main Sewer system of Danube bank on the Buda side) [in Hungarian]. MSc Thesis, Eötvös Loránd University

Surbeck H (2000) Alpha spectrometry sample preparation using selectively adsorbing thin films. Appl Radiat Isot 53:97-100. https://doi.org/10.1016/S0969-8043(00)00119-6

Leél-Ốssy Sz (1995) A Rózsadomb és környékének különleges barlangjai (Special caves of Rózsadomb on Buda and its environs) [in Hungarian]. Földt Közl 125(3-4):363-432

Leél-Őssy Sz, Surányi G (2003) Peculiar hydrothermal caves in Budapest, Hungary. Acta Geol Hung 46:407-436. https://doi.org/10.1556/AGeol.46.2003.4.5

Takács-Bolner K, Kraus S (1989) A melegvizes eredetű barlangok kutatásának eredményei (Results of research into caves with thermal water origins) [in Hungarian]. Karszt Barl I-II:61-66

Tazaki K (2009) Observation of microbial mats in radioactive hot springs. Sci Rep Kanazawa Univ 53:25-37

Tóth J (1963) A theoretical analysis of groundwater flow in small drainage basins. J Geophys Res 68:47954812. https://doi.org/10.1029/JZ068i016p04795

Watermark Numerical Computing (2016) PEST_model-independent parameter estimation user manual part I: PEST, SENSAN and Global Optimisers

Weidinger T, Nagy B, Mádlné Szőnyi J, Bodor P, Salavec P, Tordai Á (2016) Terepi mérések a Gellért-hegy belsejétôl a Száraz Andokig (Field measurements from the inside of the Gellért Hill to the Dry Andes) [in Hungarian]. In: Pongrácz R, Mészáros R (eds) Kutatási és operatív feladatok meteorológusként (Research and operative challanges as a meteorologist). Egy Met Füz 27:162-172

Zhang DD, Zhang Y, Zhu A, Cheng X (2001) Physical mechanisms of river waterfall tufa (travertine) formation. J Sediment Res 71(1):205-216. https://doi.org/10.1306/061600710205

\section{Affiliations}

\section{Petra Kovács-Bodor ${ }^{1}$ D $\cdot$ Dóra Anda ${ }^{2} \cdot$ Laura Jurecska $^{2} \cdot$ Mihály Óvári $^{3}$. Ákos Horváth ${ }^{4}$. Judit Makk ${ }^{2}$. Vincent Post ${ }^{5} \cdot$ Imre Müller $^{1}$ - Judit Mádl-Szőnyi ${ }^{1}$}

Dóra Anda

andadora@caesar.elte.hu

Laura Jurecska

jurecskalaura@gmail.com

Mihály Óvári

ovari.mihaly@okologia.mta.hu

Ákos Horváth

akos@ludens.elte.hu

Judit Makk

makkjudit@gmail.com

Vincent Post

Vincent.Post@bgr.de

Imre Müller

imremuller40@gmail.com

Judit Mádl-Szőnyi

szjudit@ludens.elte.hu 
1 József and Erzsébet Tóth Endowed Hydrogeology Chair, Department of Physical and Applied Geology, ELTE Eötvös Loránd University, Pázmány Péter stny. 1/C., Budapest 1117, Hungary

2 Department of Microbiology, ELTE Eötvös Loránd University, Pázmány Péter stny. 1/C., Budapest 1117, Hungary

3 MTA Centre for Ecological Research, Danube Research Institute, Karolina út 29., Budapest 1113, Hungary

4 Department of Nuclear Physics, ELTE Eötvös Loránd University, Pázmány Péter stny. 1/A., Budapest 1117, Hungary

5 Federal Institute for Geosciences and Natural Resources, Hannover, Germany 